Article

\title{
Hydroxyproline-Rich Glycoproteins as Markers of Temperature Stress in the Leaves of Brachypodium distachyon
}

\author{
Artur Pinski ${ }^{1}{ }^{\oplus}$, Alexander Betekhtin ${ }^{1, *} \mathbb{D}$, Katarzyna Sala ${ }^{2}$, Kamila Godel-Jedrychowska ${ }^{2}$, \\ Ewa Kurczynska ${ }^{2, *}$ and Robert Hasterok ${ }^{1}$ (D) \\ 1 Department of Plant Anatomy and Cytology, Faculty of Biology and Environmental Protection, \\ University of Silesia in Katowice, 40-032 Katowice, Poland; apinski@us.edu.pl (A.P.); \\ robert.hasterok@us.edu.pl (R.H.) \\ 2 Department of Cell Biology, Faculty of Biology and Environmental Protection, \\ University of Silesia in Katowice, 40-032 Katowice, Poland; katarzyna.sala@us.edu.pl (K.S.); \\ kgodel@us.edu.pl (K.G.-J.) \\ * Correspondence: alexander.betekhtin@us.edu.pl (A.B.); ewa.kurczynska@us.edu.pl (E.K.); \\ Tel.: +48-32-2009-484 (A.B.); +48-32-2009-447 (E.K.)
}

Received: 7 May 2019; Accepted: 23 May 2019; Published: 25 May 2019

\begin{abstract}
Plants frequently encounter diverse abiotic stresses, one of which is environmental thermal stress. To cope with these stresses, plants have developed a range of mechanisms, including altering the cell wall architecture, which is facilitated by the arabinogalactan proteins (AGP) and extensins (EXT). In order to characterise the localisation of the epitopes of the AGP and EXT, which are induced by the stress connected with a low $\left(4^{\circ} \mathrm{C}\right)$ or a high $\left(40^{\circ} \mathrm{C}\right)$ temperature, in the leaves of Brachypodium distachyon, we performed immunohistochemical analyses using the antibodies that bind to selected AGP (JIM8, JIM13, JIM16, LM2 and MAC207), pectin/AGP (LM6) as well as EXT (JIM11, JIM12 and JIM20). The analyses of the epitopes of the AGP indicated their presence in the phloem and in the inner bundle sheath (JIM8, JIM13, JIM16 and LM2). The JIM16 epitope was less abundant in the leaves from the low or high temperature compared to the control leaves. The LM2 epitope was more abundant in the leaves that had been subjected to the high temperatures. In the case of JIM13 and MAC207, no changes were observed at the different temperatures. The epitopes of the EXT were primarily observed in the mesophyll and xylem cells of the major vascular bundle (JIM11, JIM12 and JIM20) and no correlation was observed between the presence of the epitopes and the temperature stress. We also analysed changes in the level of transcript accumulation of some of the genes encoding EXT, EXT-like receptor kinases and AGP in the response to the temperature stress. In both cases, although we observed the upregulation of the genes encoding AGP in stressed plants, the changes were more pronounced at the high temperature. Similar changes were observed in the expression profiles of the EXT and EXT-like receptor kinase genes. Our findings may be relevant for genetic engineering of plants with increased resistance to the temperature stress.
\end{abstract}

Keywords: arabinogalactan proteins; Brachypodium distachyon; cell wall; extensins; immunohistochemistry; leaf; RT-qPCR; temperature stress

\section{Introduction}

Plant growth and productivity are compromised by various abiotic stresses, among which are high and low temperature stress. Even short periods of temperature stress may significantly decrease the yield, especially when it occurs during the crucial stages of plant development [1]. As was predicted, 
heat waves and other extreme temperature events are to become more intense, frequent and long-lasting because of global climate change [2]. Thus, thermal stresses must be better understood in the context of the response and adaptation of plants, which may enable crops with improved thermotolerance to be obtained and bred [3].

Brachypodium distachyon L. Beauv. (Brachypodium), which is a member of the Pooideae subfamily, is a wild annual grass species that is widespread in the regions of the Mediterranean basin, Western Europe, the Middle East, south-west Asia, north-east Africa, North and South America and Australia. It is closely related to many temperate zone key cereals, including wheat, barley, rye, oats and various forage grasses [4]. Due to its numerous favourable biological features such as a relatively small nuclear genome that ranges from $270 \mathrm{Mb}$ to $350 \mathrm{Mb}$ (depending on the methodology that is used), small stature, self-fertility, a life cycle of less than four months and undemanding growth requirements, $B$. distachyon constitutes an excellent model species [5].

Low-temperature stress results in the downregulation of many photosynthesis-related proteins and, at the same time, the upregulation of the proteins that are involved in reactive oxygen species (ROS) scavenging, redox adjustment, cytoskeletal rearrangements, cryoprotection and cell wall remodelling [6]. Similar results are observed in plants that are stressed by a high temperature [7]. Though the cell wall structure is not primarily altered under heat stress, numerous studies have indicated various changes in its architecture. In low temperature stress, changes in the cell wall rigidity may be an important factor in thermotolerance. Changes in the cell wall are more pronounced in roots because they are more sensitive to temperature stresses than the aerial parts of a plant, though the adverse effect of such stress on leaves directly affects plant productivity. Alterations in the cell wall in response to temperature stress concern cellulose and hemicelluloses biosynthesis, pectin modifications by pectin methylesterases, lignin biosynthesis and changes in the abundance of hydroxyproline-rich glycoproteins (HRGP) [8].

HRGP are usually divided into three complex multigene families: (i) arabinogalactan proteins (AGP); (ii) extensins (EXT); and (iii) proline-rich proteins [9]. AGP are further divided into four sub-families according to their polypeptide core: classical AGP, lysine-rich AGP (Lys-rich AGP), arabinogalactan peptides (AG peptides) and fasciclin-like AGP (FLA) [10]. Typically, AGP are strongly O-glycosylated and most of them have glycosylphosphatidylinositol (GPI) anchors that attach the proteins to the plasma membrane, though some of them can be released into the wall matrix via GPI cleavage [11]. In connection with their abundance, ubiquitous presence and localisation, AGP play a crucial role in various biological processes such as cell division, cellular communication, programmed cell death, organ abscission, plant-microbe interactions, plant defence and growth as well as in the reproductive processes [12-14]. A decrease in the amount of AGP has also been linked with the loss of embryogenic potential in callus cultures of B. distachyon [15]. Despite many studies on the role of AGP in plant development, our understanding of their role in the reaction of the plant to temperature stress is still quite limited. Recent studies have shown that temperature stress strongly affects the distribution and content of AGP in the stigma and ovule of Solanum lycopersicum as well as in banana leaves and roots, which may indicate that AGP are differentially regulated in the response to temperature stress and that their expression and distribution is tissue specific [16-18].

Based on a bioinformatic analysis, EXT were divided into seven classes: classical, short, leucine-rich repeat extensins (LRX), proline-rich extensin-like receptor kinases (PERK), formin-homolog EXT (FH EXT), chimeric and long chimeric EXT. EXT are characterised by the presence of serine, which is followed by three to five proline residues. These prolines are hydroxylated and glycosylated [19]. EXT are known to play important roles in the response to wounding and pathogen infections [20]. This family was also indicated as playing an important role in root-microbe interactions [14,21]. A study on a B. distachyon callus showed that one of the chimeric EXT could be considered to be a good marker for embryogenic cells [15]. A chimeric leucine-rich repeat/extensin, LRX1, was shown to be required for root hair morphogenesis in Arabidopsis thaliana [22]. However, information on the synthesis and location of extensins in response to temperature stress is scarce. 
Thus, the aim of this work was to investigate any changes in the distribution of the epitopes of AGP and EXT in B. distachyon leaves through an immunostaining analysis. This approach enabled the distribution of these epitopes and the changes in their leaves that had been stressed by a high or low temperature to be determined. We also determined the level of transcript accumulation of selected genes encoding EXT, EXT-like receptor kinases, and FLA in the leaves of $B$. distachyon that had been stressed by a high or low temperature using RT-qPCR.

\section{Results}

\subsection{Distribution of the Epitopes of AGP and EXT in Leaves in Response to Temperature Stress}

The distribution of the epitopes of AGP (JIM8, JIM13, JIM16, LM2 and MAC207), pectin/AGP (LM6) and EXT (JIM11, JIM12 and JIM20) in the leaves of B. distachyon under normal $\left(21^{\circ} \mathrm{C}\right.$ ) and thermal stress conditions $\left(4\right.$ and $40^{\circ} \mathrm{C}$ ) was determined. Considering the phenotype, we observed no visible changes induced by the thermal stress. The general anatomy of a B. distachyon leaf is shown in Figure 1. In order to present the results clearly, only the antibodies for which changes in their localisation or the intensity of the fluorescence signal in different temperature conditions were observed, are presented in the main text. Figures A1-A5 show the localisation of the remaining epitopes, in which no changes were identified in their response to temperature treatment.

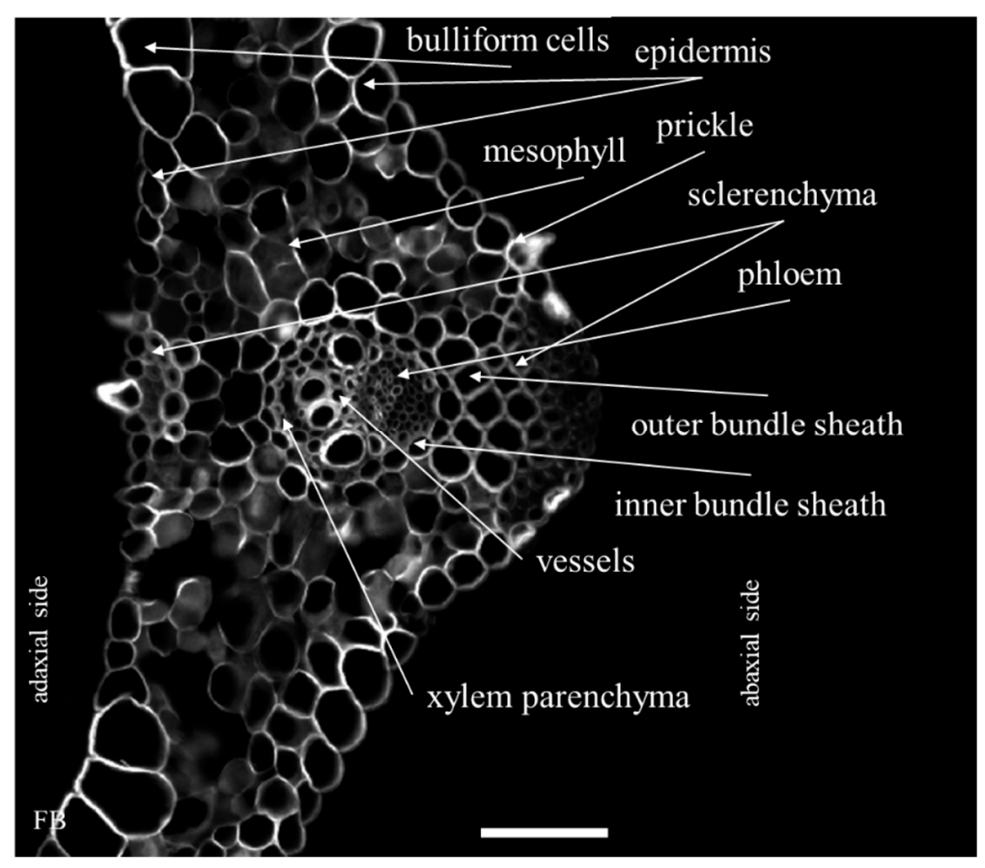

Figure 1. A cross-section of a B. distachyon leaf through the major vascular bundle (nomenclature according to Botha [23]) that had been stained with a fluorescent brightener (FB). Scale bar: $50 \mu \mathrm{m}$.

The occurrence of the epitopes of AGP was mostly associated with the vascular bundle. The JIM8 epitope was present in the walls and cellular compartments of the inner bundle sheath cells and phloem (Figure 2D-F). This epitope also occurred in the sclerenchyma fibres that were located next to the vascular bundle (Figure A1A-C) or were developing at the edge of the leaf blade (Figure A1D-F). The presence and spatial distribution of the JIM8 epitope were diverse at different temperatures. The JIM8 epitope was less represented in the leaves that were growing at a low temperature (Figure 2A-C). However, in the leaves that had been subjected to a temperature of $40^{\circ} \mathrm{C}$, an increase in the intensity of fluorescence signal was observed in the walls of phloem cells compared to the leaves that were growing at a low temperature (Figure 2G-I). JIM13 was found at the same locations as the JIM8 epitope (Figure A2A-F) and was additionally detected in the intercellular compartments (under intercellular compartments we 
define the localisation of epitope within the cytoplasm endomembrane system or organelles that are associated with the biosynthesis and secretion pathway to the wall, however these are not visible on the light microscope level [24]) of the prickles (Figure A2G-I). There were no changes in the distribution of the JIM13 epitope or in the intensity of the fluorescence signal between the analysed temperatures. The JIM16 epitope in the control leaves was present in a low amount in the intercellular compartments of the inner and outer bundle sheath cells and phloem as well as in the xylem parenchyma (Figure 3D-F). This epitope was not detected in the xylem parenchyma in the leaves that were growing at $40{ }^{\circ} \mathrm{C}$ (Figure 3G-I) and in the leaves from $4{ }^{\circ} \mathrm{C}$, the presence of this epitope was not detected (apart from single dots in the vascular bundle cells; Figure 3A-C). Another AGP epitope, LM2, occurred in the cellular compartments of bundle sheath, phloem and xylem parenchyma in the control leaves (Figure $4 \mathrm{D}-\mathrm{F})$. At a low temperature $\left(4^{\circ} \mathrm{C}\right)$, the occurrence of this epitope was very low (Figure $4 \mathrm{~A}-\mathrm{C}$ ), while in the leaves that were growing at a high temperature, it was more abundant (Figure 4G-I) compared to the control plants (Figure 4D-F). Additionally, LM2, was detected in the intercellular compartments and/or walls of the epidermis and bulliform cells in the leaves from plants that had been subjected to a high temperature (Figure 5A-I). A signal in the mesophyll cells was detected only in the leaves that were growing at $40{ }^{\circ} \mathrm{C}$ (Figure 5G-I). The MAC207 epitope was present in large amounts in the intercellular compartments and/or walls of the phloem cells, mesophyll cells and bulliform cells (Figure A3A-F). At all of the temperatures, its fluorescence had a similar cellular distribution and intensity. The LM6 epitope was detected abundantly in the phloem, xylem parenchyma and, in lower amounts, in the cellular compartments and/or walls of the outer bundle sheath (Figure 6D-F). The fluorescence signal of this epitope in the leaves that were growing at $40{ }^{\circ} \mathrm{C}$ was more intense compared to the other temperature treatments (Figure 6G-I vs. Figure 6A-F). Outside the vascular bundle, LM6 was present in the cell walls and/or in the intercellular compartments of the mesophyll cells (Figure A4A-C).
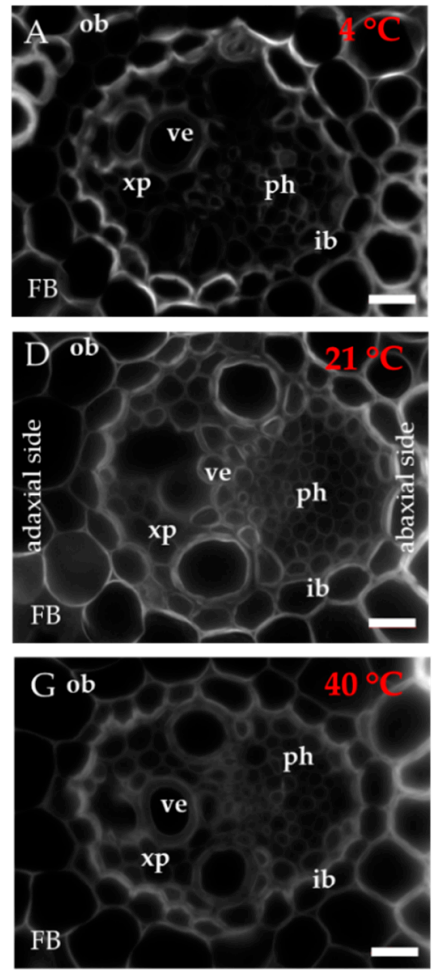
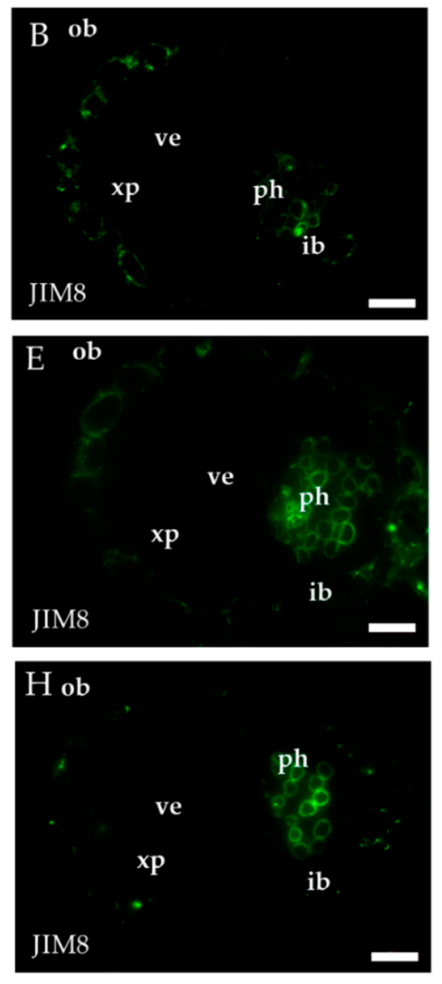
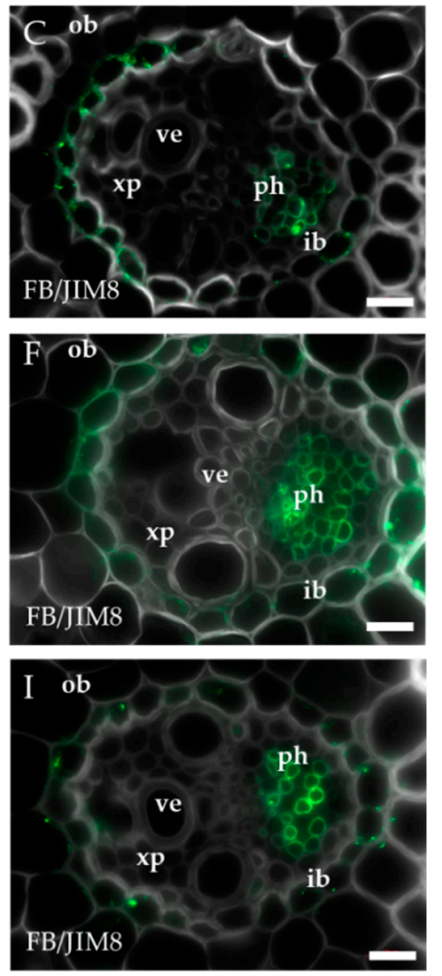

Figure 2. Immunolocalisation of the JIM8 epitope (A-I) in cross-sections of the $B$. distachyon leaves, (A-I): through the major vascular bundle. $(\mathrm{A}-\mathrm{C}): 4{ }^{\circ} \mathrm{C} ;(\mathbf{D}-\mathbf{F}): 2{ }^{\circ} \mathrm{C} ;(\mathrm{G}-\mathbf{I}): 40^{\circ} \mathrm{C}$. Abbreviations: FBfluorescent brightener, ib-inner bundle sheath, ob-outer bundle sheath, ph-phloem, ve-vessels, $\mathrm{xp}$-xylem parenchyma. The green colour shows epitope occurrence. Scale bars: $10 \mu \mathrm{m}$. 

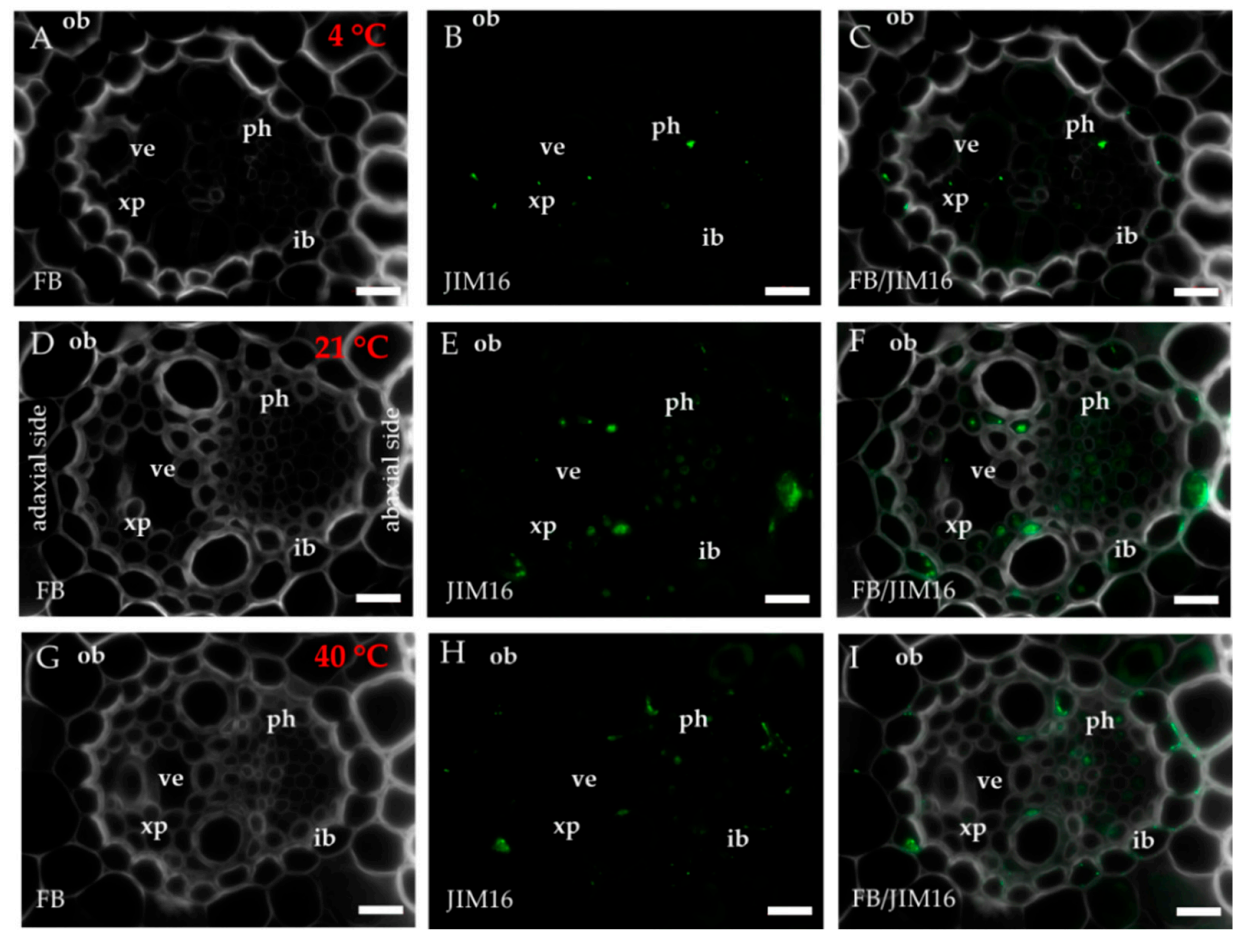

Figure 3. Immunolocalisation of the JIM16 epitope (A-I) in cross-sections of the B. distachyon leaves, (A-I): through the major vascular bundle. (A-C): $4{ }^{\circ} \mathrm{C} ;(\mathrm{D}-\mathrm{F}): 21^{\circ} \mathrm{C} ;(\mathrm{G}-\mathrm{I}): 40^{\circ} \mathrm{C}$. Abbreviations: FB-fluorescent brightener, ib—inner bundle sheath, ob—outer bundle sheath, ph—phloem, ve—vessels, xp—xylem parenchyma. The green colour shows epitope occurrence. Scale bars: $10 \mu \mathrm{m}$.
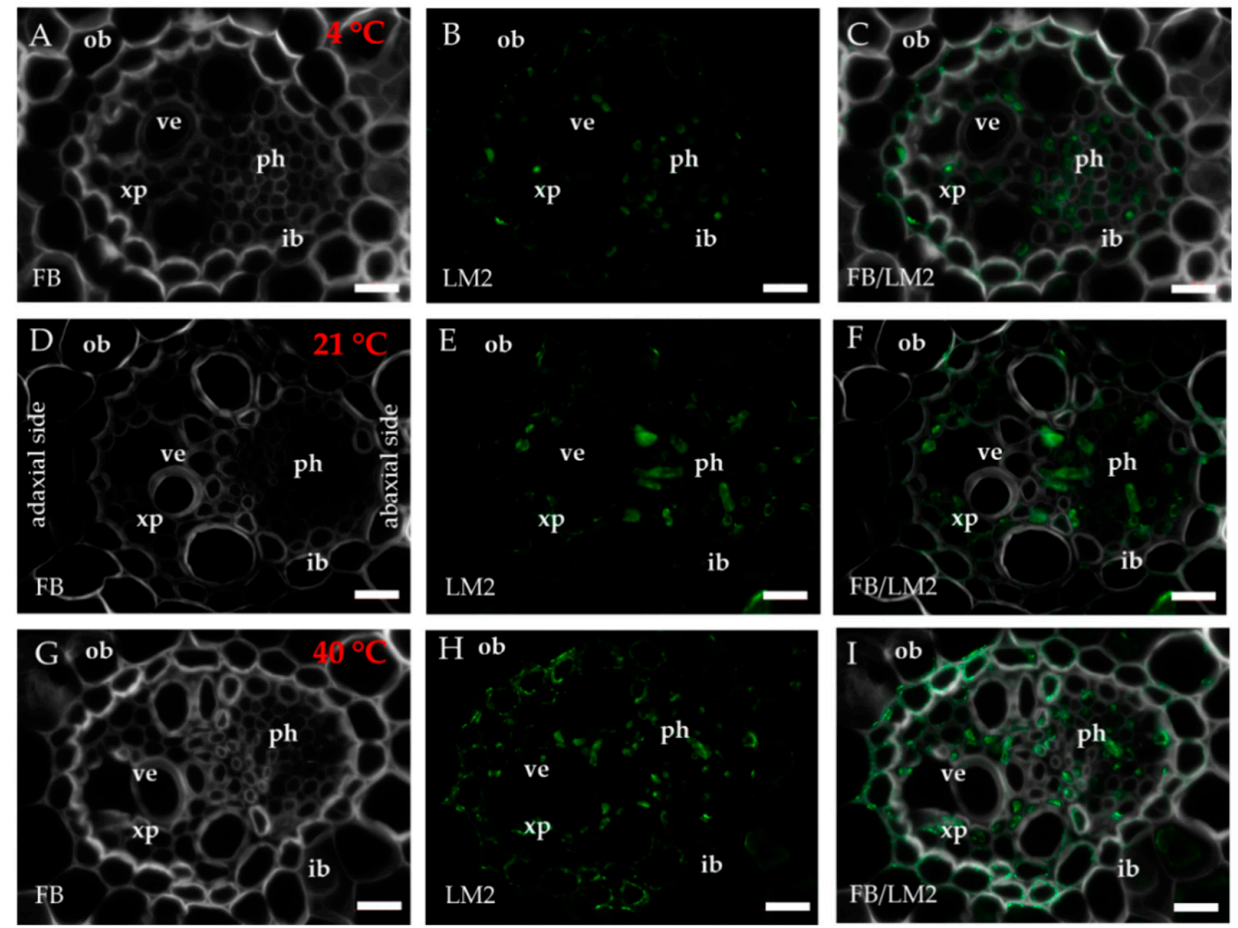

Figure 4. Immunolocalisation of the LM2 epitope (A-I) in cross-sections of the B. distachyon leaves, (A-I): through the major vascular bundle. (A-C): $4{ }^{\circ} \mathrm{C}$; (D-F): $21^{\circ} \mathrm{C} ;(\mathrm{G}-\mathrm{I}): 40^{\circ} \mathrm{C}$. Abbreviations: FB-fluorescent brightener, ib —inner bundle sheath, ob—outer bundle sheath, ph—phloem, ve—vessels, $\mathrm{xp}$ —xylem parenchyma. The green colour shows epitope occurrence. Scale bars: $10 \mu \mathrm{m}$. 

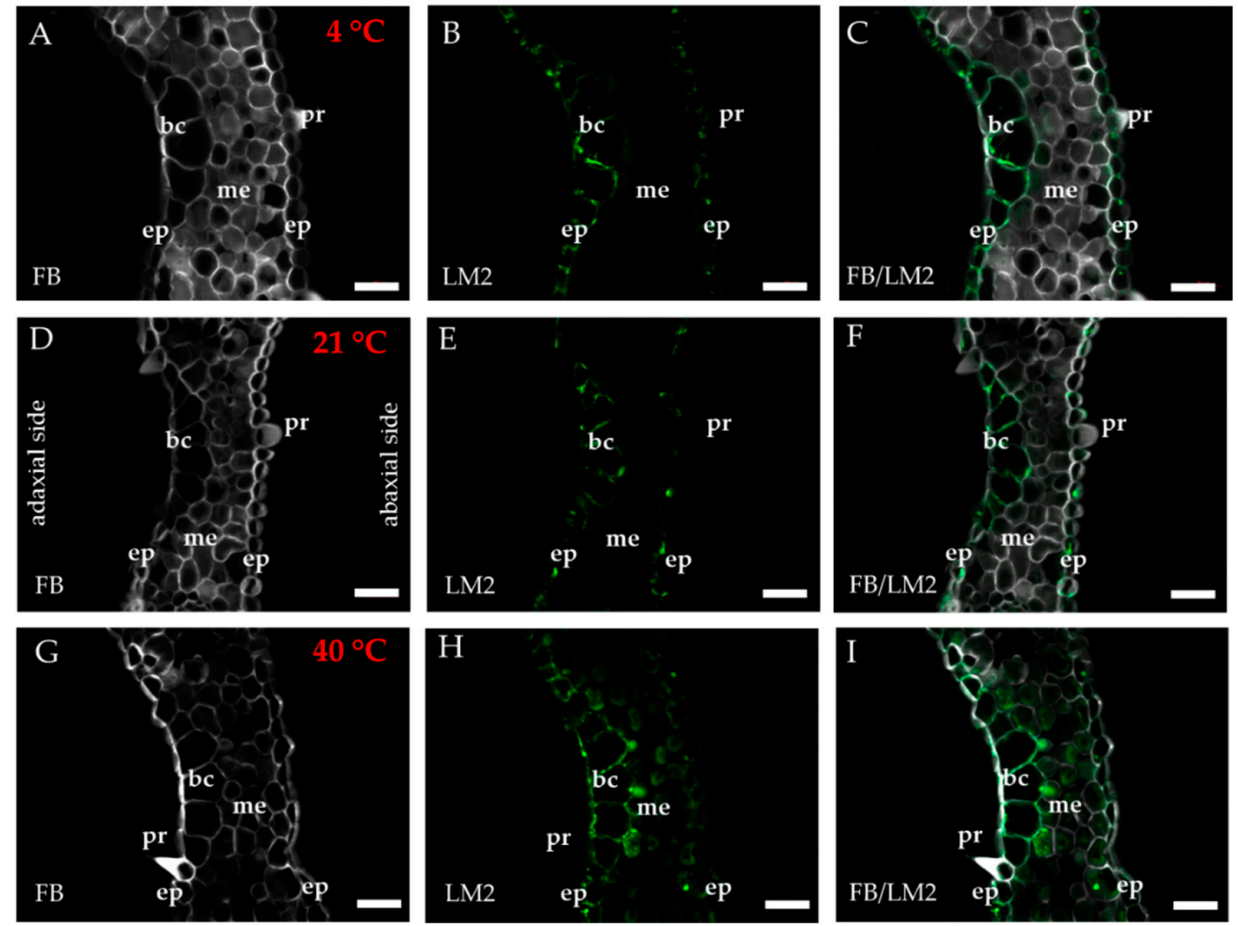

Figure 5. Immunolocalisation of the LM2 epitope (A-I) in cross-sections of the B. distachyon leaves, (A-I): through the mesophyll and bulliform cells. (A-C): $4{ }^{\circ} \mathrm{C} ;(\mathbf{D}-\mathbf{F}): 21^{\circ} \mathrm{C}$; (G-I): $40^{\circ} \mathrm{C}$. Abbreviations: bc — bulliform cells, ep—epidermis, FB—fluorescent brightener, me-mesophyll, pr-prickle. The green colour shows epitope occurrence. Scale bars: $20 \mu \mathrm{m}$.
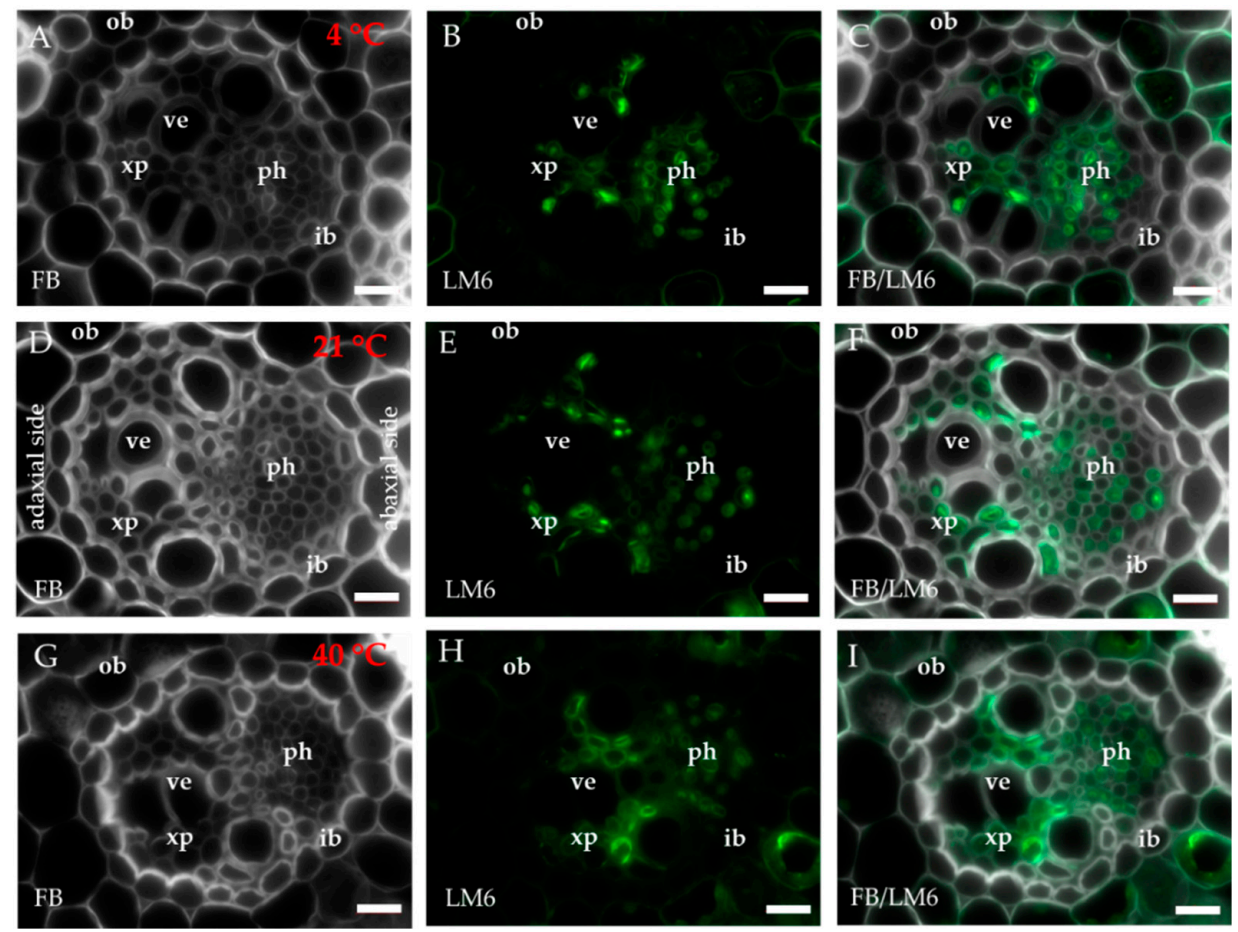

Figure 6. Immunolocalisation of the LM6 epitope (A-I) in cross-sections of the B. distachyon leaves, (A-I): through the major vascular bundle. (A-C): $4{ }^{\circ} \mathrm{C}$; (D-F): $21{ }^{\circ} \mathrm{C} ;(\mathbf{G}-\mathbf{I}): 40{ }^{\circ} \mathrm{C}$. Abbreviations: FB-fluorescent brightener, ib —inner bundle sheath, ob—outer bundle sheath, ph—phloem, ve — vessels, $\mathrm{xp} — \mathrm{xylem}$ parenchyma. The green colour shows epitope occurrence. Scale bars: $10 \mu \mathrm{m}$. 
All three extensin epitopes that are recognised by the JIM11, JIM12 and JIM20 antibodies were mostly associated with the mesophyll cells. The JIM11 epitope was present only in the mesophyll cell walls (Figure A5A-C). In addition to occurring in the mesophyll cell walls (Figure A5D-F), JIM12 was also found in the walls of some of the outer bundle sheath cells and vessels (Figure A5G-I). The occurrence of the JIM20 epitope was similar to JIM12 (Figure A5J-O), but had an additional location in the walls and/or cellular compartments of the phloem (Figure A5M-O). All three extensin epitopes occurred abundantly and there were no differences in their distribution or in the intensity of the fluorescence signal among the temperatures that were analysed.

\subsection{Analysis of the Level of Transcript Accumulation of the Genes Encoding the FLA, EXT and EXT-Like Receptor Kinases}

In this study, we determined the level of transcript accumulation of five different genes encoding FLA (Bradi4g34420, Bradi2g00220, Bradi5g18950, Bradi3g39740 and Bradi2g60270). The transcript accumulation levels of Bradi4g34420 and Bradi2g00220 increased in both temperatures, 4 and $40{ }^{\circ} \mathrm{C}$, compared to the control conditions (Figure 7A). The increase in expression of the Bradi4g34420 gene at $40{ }^{\circ} \mathrm{C}$ (4.7-fold) was higher than at $4{ }^{\circ} \mathrm{C}$ (1.9-fold) (Figure 7A). In the case of the Bradi5g18950 gene, the expression at $4{ }^{\circ} \mathrm{C}$ was approximately the same as in the control, while its expression at $40{ }^{\circ} \mathrm{C}$ was 6-fold higher (Figure 7A). A similar pattern of expression was found for the Bradi3g39740 gene, though there was only a slight (1.7-fold) increase in its expression at $4{ }^{\circ} \mathrm{C}$ (Figure 7B). Interestingly, there was a dramatic increase (28-fold) in the expression of this gene at $40^{\circ} \mathrm{C}$. Notably, the expression of the Bradi2g60270 gene was only detectable in the leaves at $40^{\circ} \mathrm{C}$. Generally, temperature stress resulted in a higher level of transcript accumulation of $F L A$, though the increase was more pronounced at $40^{\circ} \mathrm{C}$.
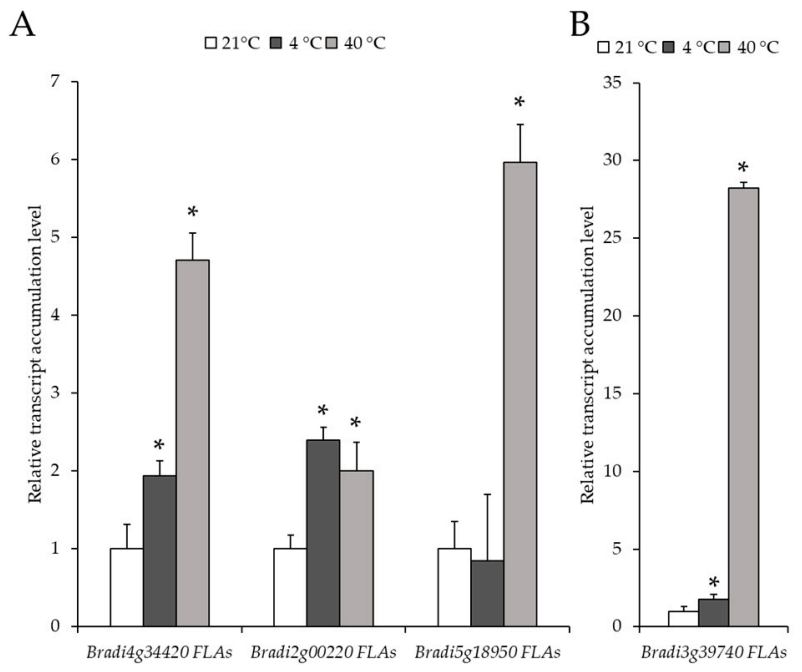

Figure 7. Relative level of transcript accumulation of the fasciclin-like AGP (FLA) genes: (A) Bradi4g34420, Bradi2g00220 and Bradi5g18950 and (B) Bradi3g39740. The relative expression levels were normalised to an internal control (Bradi1g32860, gene encoding ubiquitin) and calibrated to the control. Asterisks indicate significant differences from the control using the Student's t-test $(p<0.05$; mean $\pm \mathrm{SD}, n=3)$.

The level of transcript accumulation of nine different genes encoding EXT and EXT-like receptor kinases were also determined. Each gene was assigned to a group based on its structure: FH EXT (Bradi1g22980, Bradi3g59780 and Bradi4g03720), chimeric EXT (Bradi4g11250 and Bradi3g12902) and PERK EXT (Bradi2g00900, Bradi2g49240, Bradi1g07010 and Bradi3g31967). The level of transcript accumulation of the Bradi1g22980 gene in the treated plants was not statistically different from the control (Figure 8A). The level of transcript accumulation of two other FH EXT, Bradi3g59780 and Bradi4g03720 was only statistically higher at $40{ }^{\circ} \mathrm{C}$ (Figure 8A). Conversely, the level of transcript accumulation of the chimeric 
EXT, Bradi4g11250, increased significantly at $4{ }^{\circ} \mathrm{C}$, though there was no clear difference in its expression for the Bradi3g12902 gene (Figure 8B). When considering PERK, a higher transcript accumulation of the Bradi2g00900 gene at $4^{\circ} \mathrm{C}$ and a higher level of transcript accumulation of the Bradi2g 49240 gene at $4{ }^{\circ} \mathrm{C}$ and $40{ }^{\circ} \mathrm{C}$ was determined (Figure $8 \mathrm{C}$ ). Intriguingly, the expression of the other PERK gene, Bradi3g31967, was only observed in the temperature-stressed samples (Figure 8D). The distribution of all of the epitopes together with changes in the level of transcript accumulation of the analysed genes are summarised in Figure 9.
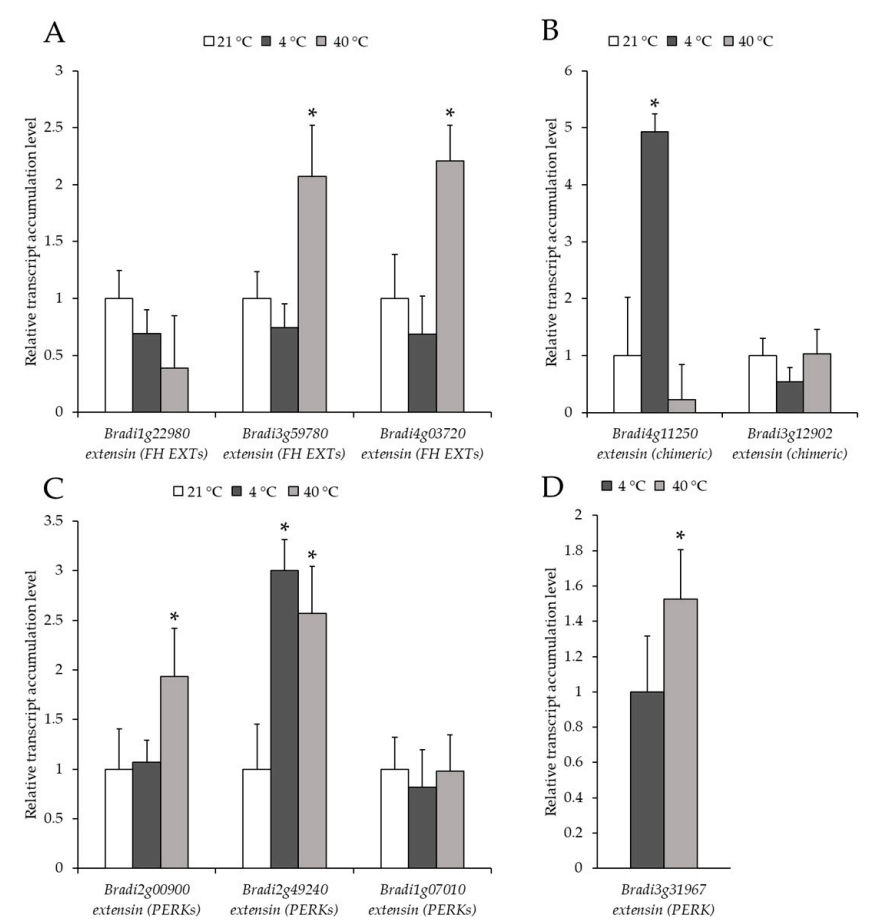

Figure 8. Relative level of transcript accumulation of the extensins (EXT) genes: (A) formin-homolog (FH) EXT: Bradi1g22980, Bradi3g59780, Bradi4g03720, (B) chimeric EXT: Bradi4g11250, Bradi3g12902, (C) proline-rich extensin-like receptor kinase (PERK): Bradi2g00900, Bradi2g49240, Bradi1g07010 and (D) Bradi3g31967. The relative expression levels were normalised to an internal control (Bradi1g32860, gene encoding ubiquitin) and calibrated to the control. Asterisks indicate significant differences from the control using the Student's t-test $(p<0.05$; mean \pm SD, $n=3)$.
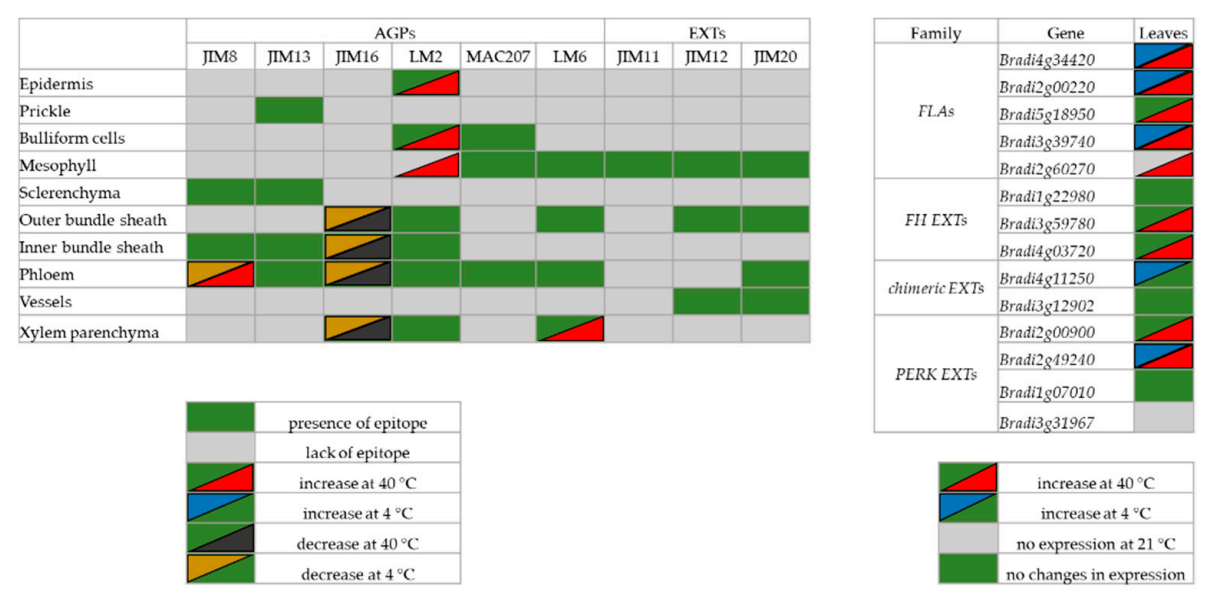

Figure 9. Consolidated results of the distribution of the epitopes EXT and AGP in the leaves of $B$. distachyon and changes in the level of transcript accumulation of the analysed genes. 


\section{Discussion}

Although immunohistochemical analyses are widely used to study changes in the chemical components of the cell wall during different developmental processes, in vivo and in vitro information concerning the presence and distribution of the cell wall proteins in leaves that have been subjected to biotic and/or abiotic stresses are scarce and remain largely unexplored $[16,18,25]$. Previous studies have primarily focused on the differential expression of AGP in response to temperatures stresses in roots and seedlings; however, the involvement of AGP in the response to temperature stress has rarely been studied in leaves [16]. For example, the transient appearance of two AGP proteins in Triticum aestivum in response to a low temperature were observed, thus indicating their involvement in the activation of the plant cell defence [16,26]. In transgenic $A$. thaliana plants, non-classical AGP improved the freezing tolerance of seedlings [27]. Temperature stress is one of the factors that limit plant growth and productivity $[2,28]$. Therefore, data showing changes in the distribution of individual cell wall components, particularly AGP, in connection with temperature stress, are particularly important as the results can be used in genetic engineering for stress tolerance [29].

In the present study, while the distribution of the epitopes of the analysed AGP and EXT was primarily observed in the major vascular bundles (nomenclature according to Botha [23]) and sclerenchyma cells, in the case of the LM2 and MAC207 epitopes, they were present in the mesophyll and epidermal cells, especially in the bulliform cells. Generally, the results for B. distachyon presented here are similar to those that have been described for banana leaves in terms of the distribution of epitopes in leaf tissues [18]. In banana, the JIM8 epitope increased in abundance at lower temperatures, thus indicating its role in the tolerance to strong chilling stress [18]. In the pistils of Solanum lycopersicum cv Micro-Tom, a high temperature strongly affected the distribution of the JIM8 epitope, which decreased in the stigma and ovule [17]. These varied results with respect to this and other epitopes mean that further intensive studies are necessary. Moreover, such results may indicate that the changes in the chemical composition of the cell walls in response to temperature stress are species-specific. In banana leaves, the presence of the JIM16 epitope was higher in a tolerant cultivar at low temperature stress, thus suggesting that these epitopes may be involved in determining the tolerance of banana to temperature stress [18]. Among the analysed epitopes, the LM2 epitope was detected in most of the leaf tissues and an increase of the LM2 epitope as a response to high temperature stress was observed. A similar distribution was detected in banana leaves, in which this epitope was found in the phloem, bundle sheath, mesophyll and epidermal cells. Low temperature treatment increased the abundance of this epitope in banana [18]. In the leaves of Tilia $x$ euchlora, the LM2 epitope was present in the epidermis, hypodermis and parenchyma cells, although as a response to salt stress [25]. Such results may indicate that this wall epitope may be a marker of the plant response to diverse stresses. The abundant presence of the LM6 antibody in B. distachyon leaves was found. As LM6 antibody exhibits a high affinity to the (1-5)- $\alpha$-L-arabinosyl residues, it detects the (1-5)- $\alpha$-L-arabinan (a pectin rhamnogalacturonan I side chain), however, it can also bind to some AGP (http://www.plantprobes.net/index.php). Thus, the increase in the fluorescence signal in the xylem parenchyma of the temperature-stressed plants may not necessarily indicate changes in the presence of AGP. The function of the arabinan side chains is not well understood and their roles are postulated to be an involvement in the rehydration of the cell wall and flexibility [30-33]. The more abundant presence of the wall components that are recognised by LM6 antibody, especially in the cytoplasmic compartments, that were observed in our study indicate that leaves react to temperature stress by synthesising and depositing (1-5)- $\alpha$-L-arabinans into the cell walls.

As has been shown in previous studies, analyses of the distribution and changes in the signal intensity of epitopes can be compared with the expression profiles of the genes encoding the proteins that are targeted by these antibodies [15,34]. In this work, we focused on the FLA that have been implicated in modulation of signalling upstream of cell wall polymer biosynthesis, remodelling, as well as in the stress response as one of the AGP sub-families [35-37]. We found an increase in the level of transcript accumulation of the FLA in response to temperature stress, which concurs with the 
immunohistochemistry observations that have been made for the LM2 antibody. It is worth noting that the increase in the level of transcript accumulation of these genes was more pronounced at the high temperature. However, in wheat, four genes encoding FLA had a decreased level of transcript accumulation in response to low temperature stress [38]. Similarly, two other FLA genes (OsFLA1 and OsFLA4) were downregulated by cold stress in rice [39]. This may reflect intrinsic differences between the analysed species or might be the result of fragmentariness of the conducted experiments, which only focus on a few of the numerous FLA genes that are present in a genome. The Bradi5g18950 gene, which was analysed in our work, exhibited a higher level of transcript accumulation at the high temperature and it was previously shown to be upregulated in a 30-day-old callus that was characterised by an increased embryogenic potential. Conversely, the Bradi3g39740 gene was linked with a gradual loss of embryogenic potential in B. distachyon [15]. Temperature stresses that are induced by low or high temperatures inhibit water uptake, which immediately leads to a slowing down of leaf growth. This observation was correlated with a loss of turgor in leaf cells and an adjustment of the osmoticum, which enables cells to regain turgor [40]. AGP are well known for their water-holding properties [41]. For example, in the resurrection plants, side chains of pectin are highly enriched in arabinose-rich polymers, including AGP. Their presence can prevent water loss during desiccation [8]. In Coffea arabica plants that had been subjected to heat stress, there were extensive changes in the cell wall of the leaves. The plants accumulated a higher content of arabinose and galactose, which may suggest that the response of coffee leaves to heat stress is related to type II arabinogalactans and pectins. Moreover, during heat stress, the palisade parenchyma cells were more separated and thinner relative to the control, which resulted in a decreased thickness of the leaves [42]. It has been hypothesised that the organs that are susceptible to water loss such as leaves increase the thickness of the cell walls, thereby limiting desiccation through the production of specific molecules such as AGP [16]. Our results seem to support this hypothesis.

Similar to the temperature stress, salt stress results in a decrease of available water due to a reduction in osmotic potential of the soil solution, which leads to a water deficit [8]. AGP have also been shown to play an important part in the salt stress response and an upregulation of AGP in salt-adapted tobacco BY-2 cell cultures was observed. It has been proposed that AGP act as a possible sodium carrier via vesicle trafficking from the apoplast to the vacuoles in salt-adapted tobacco BY-2 cells [43]. A significant upregulation of the FLA genes in the salt stress response was observed in the roots of Populus trichocarpa [44]. Moreover, AGP were found to act as pectin plasticisers [8,45]. As was shown for an FLA sos5 (salt-overly sensitive) mutant of $A$. thaliana, it exhibits a root-swelling phenotype under salt stress [46]. Further studies showed that the SOS5 protein mediates adherence via its interaction with the cell wall pectin [47]. At-FLA4 is one of the FLA genes in A. thaliana that encodes the predicted lipid-anchored glycoprotein and it was shown to positively regulate cell wall biosynthesis and root growth by modulating abscisic acid signalling. Moreover, an At-fla4 mutant was found to be sensitive to the salt stress [37]. It has been suggested that At-fla4 might interact with the pectin network via the covalent or non-covalent interactions of its glycans. At-fla4 may mechanically link pectin with the AtFei1 and AtFei2 receptor kinases and the plasma membrane, thus contributing to some biophysical properties such as swelling and interpolymer connectivity [48]. As was indicated by another inactivated mutant of $A$. thaliana, the FLA1 gene is involved in the early events of lateral root and shoot development in tissue cultures [49]. Considering the salt stress response, it is possible that the upregulation of FLA and the increased signal intensity of some of the epitopes of AGP during temperature stress may link with other cell wall polymers such as pectins and thus may modulate the signalling pathways. As has been shown by a number of studies on various species, the pectin content increases during cold stress. Conversely, it decreases during heat stress [8].

An immunohistochemical analysis of the distribution of the EXT using the JIM11, JIM12 and JIM20 antibodies showed the presence of all of these epitopes in the mesophyll and the JIM12 and JIM20 epitopes in the vessels. Although no immunohistochemical studies targeting the EXT using the JIM11, JIM12 and JIM20 antibodies were done in the leaves, the distribution of these epitopes has been 
widely studied in the callus embryos and roots [20,50-53]. For example, changes in the signal intensity of the JIM11 and JIM12 antibodies were connected with a gradual loss of embryogenic potential in B. distachyon callus cultures [15]. Zhang, et al. [54] showed that the EXT that are recognised by the JIM20 antibody were present in the pollen tubes and transmitting tissue of Nicotiana tabacum and that the application of hydroxyproline synthesis inhibitor, 3,4-dehydro-L-proline, decreased pollen tube growth. However, studies dedicated to the role of EXT in abiotic stress and especially temperature stress are still scarce. In our study, while we did not observe any changes in the selected epitopes of the EXT in the mesophyll, outer bundle sheath, phloem or vessels at the level of the immunohistochemical analyses, we found an increase of EXT and EXT-like receptor kinase level of transcript accumulation in the response to temperature stresses, especially during the high temperature stress. This may be partially explained by the fact that we used only three antibodies that bind to the EXT, but it is possible that the application of other anti-EXT antibodies could reveal some changes. Additionally, the effectiveness of immunohistochemical analyses is limited, since it does not provide sufficient resolution and does not focus on individual genes, as is the case of RT-qPCR-based analyses. Changes in the EXT gene expression greatly depended on the class of extensins that were being analysed as was shown for A. thaliana plants that had been subjected to low temperature stress [55]. Another transcriptomic analysis of the $A$. thaliana response to cold stress showed the downregulation of one of the PERK genes [56]. In our experiment, we found that the PERK extensin, Bradi3g31967, was only expressed in the stressed leaves. The genes that belong to this class have been found in the apical dominance, floral organ defects and root cell elongation [57]. An increased accumulation level of the PERK4 gene transcript in $A$. thaliana was observed in response to abscisic acid, which is a key regulator of abiotic stress tolerance in plants [58,59]. PERK1 mRNA from Brassica napus was shown to be dramatically and rapidly accumulated in response to wounding and moderately accumulated in response to infection by the fungal pathogen Sclerotinia sclerotiorum [60]. Interestingly, the LRX proteins were found to regulate salt tolerance in $A$. thaliana. A triple mutant in the $L R X$ genes exhibited a severe salt hypersensitivity and these genes were determined to be an important sensor of the cell wall integrity signals [61]. Moreover, recent studies have hinted at the role of EXT in the plant defence against phytopathogens as well as in interactions with beneficial microorganisms [14,21,62]. EXT have also been implicated in aluminium resistance and its accumulation in the cell walls of pea roots was observed [63]. The changes in the plant cell wall in response to temperature stress are diverse and not only include AGP and EXT, but also alterations in cellulose, hemicellulose, pectin and lignin biosynthesis [8]. Further investigations into the changes in cell wall proteomes could unravel the involvement of other proteins in the stress response because the proteome of the $B$. distachyon cell walls is complex and consists of at least 594 proteins [64-68].

\section{Materials and Methods}

\subsection{Plant Material}

The plants of the B. distachyon reference genotype Bd21 that were used is this experiment were cultivated in pots that had been filled with soil mixed with vermiculite at a ratio of 3:1 in a greenhouse. The seeds of $B$. distachyon genotype Bd21 (accession number: PI 254867) were sourced from the collection held by the United States Department of Agriculture-National Plant Germplasm System. The plants were grown in the greenhouse under a $16 \mathrm{~h} / 8 \mathrm{~h}$ light/dark photoperiod at $21 \pm 1{ }^{\circ} \mathrm{C}$ and were illuminated by lamps emitting white light at an intensity of $10000 \mathrm{~lx}$. For the low temperature stress, the plants were incubated at $4{ }^{\circ} \mathrm{C}$ for $24 \mathrm{~h}$ and for the high temperature stress, the plants were incubated at $40^{\circ} \mathrm{C}$ for $24 \mathrm{~h}$ in growing chambers [69]. Plants at the fourth stage of principal growth according to the Hong, et al. [70] were used in this experiment. This stage is referred to as booting and is characterised by the emergence of the head at the top of the growing shoot. The flag leaf was harvested and used to isolate the RNA and to perform the RT-qPCR analysis. For the immunohistochemistry 
analysis, the middle part of the leaf was collected because this permitted clear observations of the major vascular bundle, epidermis, bulliform cells, mesophyll and sclerenchyma.

\subsection{Sample Preparation}

To determine the chemistry of the cell wall, a set of monoclonal antibodies against the specific cell wall epitopes of the AGP (antibodies JIM8, JIM13, JIM16, LM2, MAC207), pectin/AGP (LM6) and EXT (JIM11, JIM12 and JIM20) (Plant Probes, Leeds, UK) were used. The references and information on the antibodies are shown in Table 1. The leaves were excised, fixed and embedded in Steedman's wax [20,71]. Transverse sections of the leaf blade ( $7 \mu \mathrm{m}$ thick) were cut using a HYRAX M40 rotary microtome (Zeiss, Oberkochen, Germany) and collected on microscopic slides coated with poly-L-lysine (Menzel Gläser, Braunscheig, Germany).

\subsection{Immunohistochemistry}

The sections were de-waxed and rehydrated in an ethanol series (three times in 100, 90 and 50\% ethanol in phosphate buffered saline PBS, $v / v$, each for $10 \mathrm{~min}$ ) and PBS (10 $\mathrm{min}$ ) [71]. The detailed procedure for immunochemical analysis and histological section observation was as previously described [20]. The slides were stained with $0.01 \%(w / v)$ fluorescent brightener 28 (FB) (Sigma-Aldrich, St. Louis, MO, USA) in PBS, which was used to visualise cell walls due to its affinity to cellulose. Two biological replicates were performed with at least eight sections for each replicate.

\section{4. $R T-q P C R$}

In order to characterise the level of transcript accumulation of the selected genes, RT-qPCR was performed using a LightCycler ${ }^{\circledR} 480$ SYBR Green I Master in a LightCycler ${ }^{\circledR} 480$ Real-Time PCR System (Roche, Basel, Switzerland). The total RNA was isolated from the leaves of B. distachyon. The primers used in this research are shown in Table A1. The genes encoding extensins with their division into classes were as previously described [19]. The FLA genes were selected based on the annotation found in the Phytozome database (https://phytozome.jgi.doe.gov/pz/portal.html). The detailed procedure for RT-qPCR was as in Betekhtin, et al. [72]. Briefly, the isolated RNA were treated with the DNase (QIAGEN, Hilden, Germany), and subsequently used for first-strand cDNA generation. Samples were run in the LightCycler ${ }^{\circledR} 480$ Real-Time PCR System (Roche, Basel, Switzerland). The PCR conditions were as follow: $5 \mathrm{~min}$ at $95{ }^{\circ} \mathrm{C}, 45$ cycles of $10 \mathrm{~s}$ at $95{ }^{\circ} \mathrm{C}, 20 \mathrm{~s}$ at $60^{\circ} \mathrm{C}$ and $10 \mathrm{~s}$ at $72{ }^{\circ} \mathrm{C}$ with signal acquisition. Ubiquitin was used as the reference gene and analysis was performed using the $2^{-\Delta \Delta C \mathrm{~T}}$ method. The significant differences between the samples and control were calculated using the Student's $t$-test.

Table 1. The antibodies that were used for the immunocytochemistry, the epitopes they recognise and the relevant references.

\begin{tabular}{|c|c|c|}
\hline Antibody & Epitope & References \\
\hline \multicolumn{3}{|c|}{ AGP } \\
\hline JIM8 & Arabinogalactan & [73] \\
\hline JIM13 & ( $\beta)$ GlcA1->3( $\alpha)$ GalA1->2Rha & [74-76] \\
\hline JIM16 & AGP glycan & [74-76] \\
\hline LM2 & $\beta$-linked GlcA & {$[75,77]$} \\
\hline MAC207 & $(\beta)$ GlcA1->3( $\alpha)$ GalA1->2Rha & {$[74,75,78,79]$} \\
\hline \multicolumn{3}{|c|}{ Pectin/AGP } \\
\hline LM6 & (1-5)- $\alpha$-L-arabinosyl residues, can also bind to some AGP & {$[80,81]$} \\
\hline \multicolumn{3}{|c|}{ EXT } \\
\hline JIM11 & Extensin & {$[74,82]$} \\
\hline JIM12 & Extensin & [82] \\
\hline JIM20 & Extensin & {$[82]$} \\
\hline
\end{tabular}




\section{Conclusions}

In our work, we demonstrated changes in the abundance and diversified expression of the epitopes of the AGP genes encoding FLA, EXT and EXT-like receptor kinases in the leaves of B. distachyon in response to temperature stress.

The main findings are as follows:

1. An increase in the JIM8 signal in the walls of phloem cells at $40{ }^{\circ} \mathrm{C}$ and a decrease at $4{ }^{\circ} \mathrm{C}$.

2. An increase in the abundance of the LM2 epitope in the leaves of plants that had been subjected to the high temperature.

3. A decrease in the JIM16 signal intensity at 4 and $40{ }^{\circ} \mathrm{C}$.

4. The upregulation of some FLA, EXT and EXT-like receptor kinases genes in response to temperature stress $\left(4\right.$ and $\left.40^{\circ} \mathrm{C}\right)$.

5. The expression of the PERK EXT gene Bradi3g31967 only in the leaves under low and high temperature stress.

To summarise, our results extend the knowledge about the presence of these epitopes in connection with temperature stress in B. distachyon. A precise dissection of the functions of AGP and EXT in response to abiotic stresses and to temperature stress, among others, requires the use of specific mutants whose availability is still limited. However, recent developments in the site-directed mutagenesis techniques such as CRISPR/Cas9 should allow the selective targeting of these genes, which may be helpful to better understand their roles.

Author Contributions: Conceptualisation, A.P., A.B.; methodology, A.P., A.B., K.S., K.G.-J.; validation, A.P., K.S., A.B.; formal analysis, A.P., K.S., A.B.; investigation, A.P., K.S., A.B.; resources, R.H., E.K.; data curation, A.P., A.B., K.S.; writing—original draft preparation, A.P., A.B., K.S., E.K.; writing—review and editing, A.P., A.B., K.S., E.K., R.H.; visualisation, A.P.; supervision, A.B., R.H.; funding acquisition, R.H., E.K.

Funding: This research was funded by the National Science Centre Poland (grant DEC-2014/14/M/NZ2/00519).

Conflicts of Interest: The authors declare no conflict of interest.

\section{Abbreviations}

$\begin{array}{ll}\text { AG Peptides } & \text { Arabinogalactan peptides } \\ \text { AGP } & \text { Arabinogalactan proteins } \\ \text { EXT } & \text { Extensins } \\ \text { FH EXT } & \text { Formin-homolog EXT } \\ \text { FLA } & \text { Fasciclin-like AGP } \\ \text { GPI } & \text { Glycosylphosphatidylinositol } \\ \text { HRGP } & \text { Hydroxyproline-rich glycoproteins } \\ \text { LRX } & \text { Leucine-rich repeat extensins } \\ \text { Lys-rich AGP } & \text { Lysine-rich arabinogalactan proteins } \\ \text { PBS } & \text { Phosphate-buffered saline } \\ \text { PERK } & \text { Proline-rich extensin-like receptor kinases } \\ \text { ROS } & \text { Reactive oxygen species } \\ \text { RT-qPCR } & \text { Reverse transcription-quantitative polymerase chain reaction }\end{array}$




\section{Appendix A}
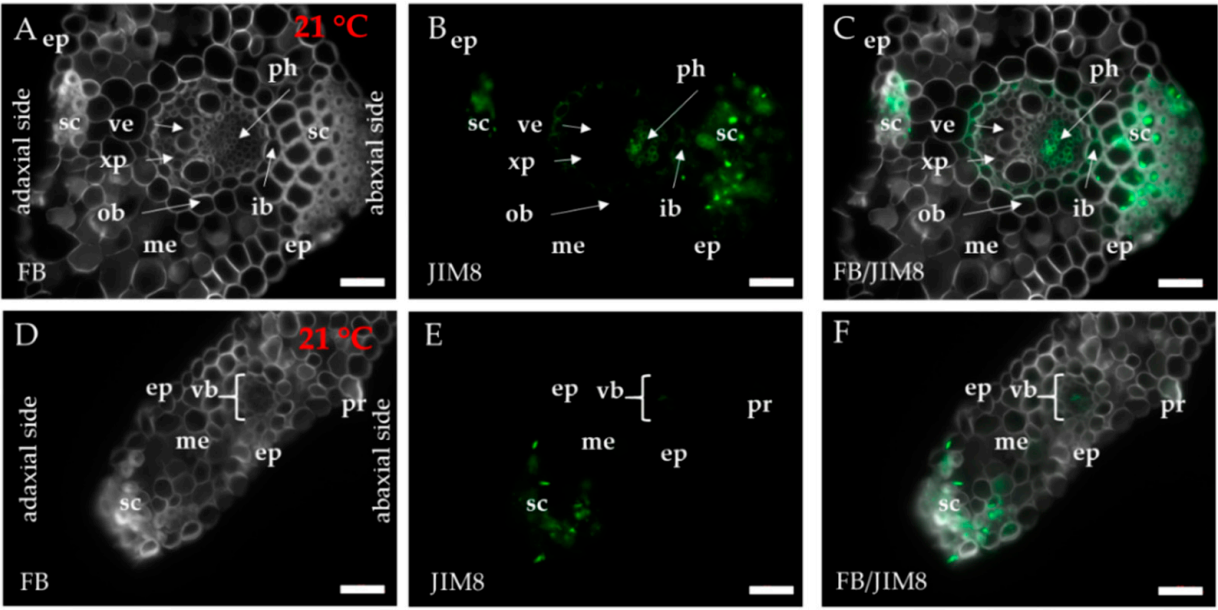

Figure A1. Immunolocalisation of the JIM8 epitope (A-F) in cross-sections of B. distachyon leaves $\left(21^{\circ} \mathrm{C}\right)$, (A-C): through the major vascular bundle; (D-F): through the edge of the leaf blade. The white arrows point to the respective parts of the leaf. Abbreviations: ep-epidermis, FB-fluorescent brightener, $\mathrm{ib}$-inner bundle sheath, me-mesophyll, ob-outer bundle sheath, ph-phloem, pr-prickle, sc-sclerenchyma, vb-vascular bundle, ve-vessels, xp-xylem parenchyma. The green colour shows epitope occurrence. Scale bars: $20 \mu \mathrm{m}$.
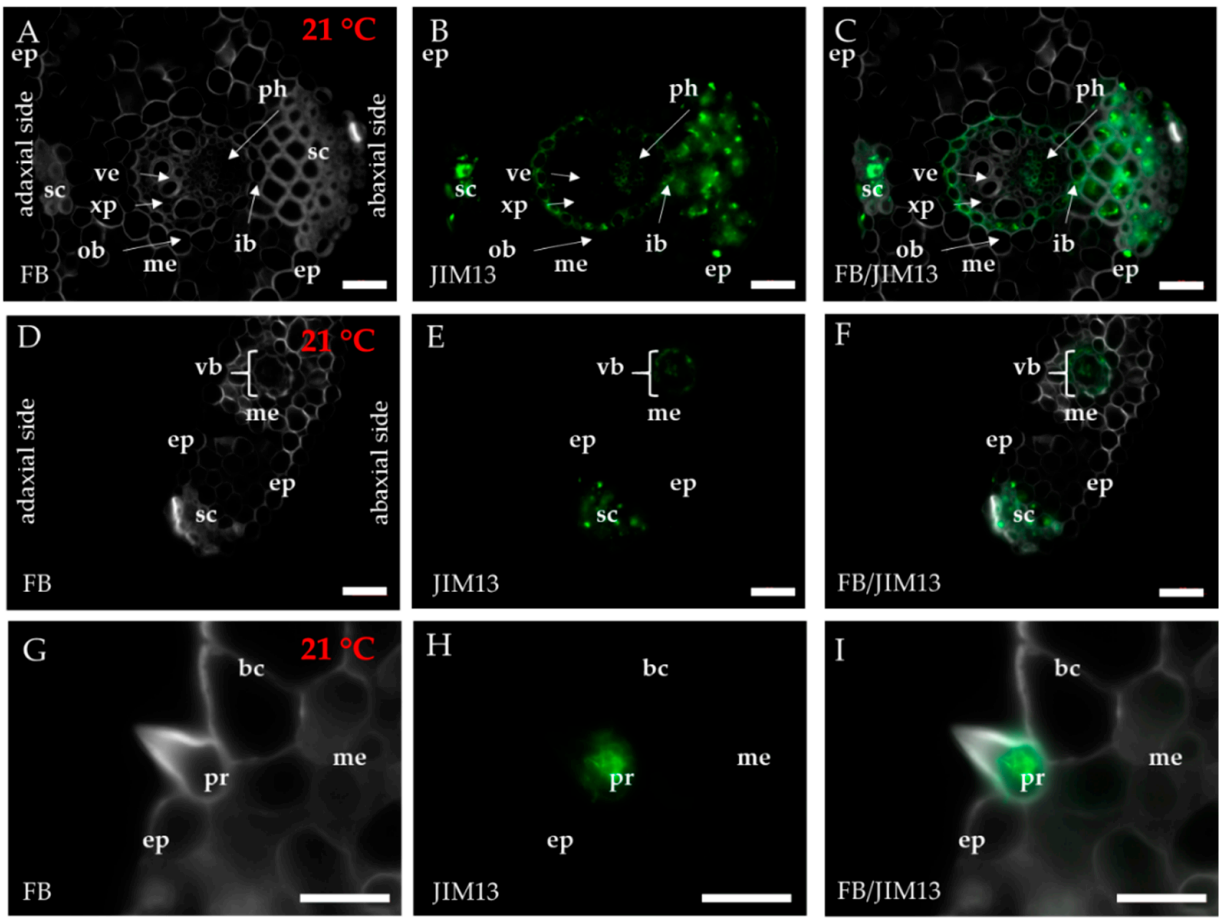

Figure A2. Immunolocalisation of the JIM13 epitope (A-I) in cross-sections of B. distachyon leaves $\left(21^{\circ} \mathrm{C}\right),(\mathbf{A}-\mathbf{C})$ : through the major vascular bundle; (D-F): through the edge of the leaf blade; (G-I): prickle. The white arrows point to the respective parts of the leaf. Abbreviations: bc-bulliform cells, ep—epidermis, FB — fluorescent brightener, ib—inner bundle sheath, me-mesophyll, ob—outer bundle sheath, ph-phloem, pr-prickle, sc—sclerenchyma, vb—vascular bundle, ve-vessels, xp—xylem parenchyma. The green colour shows epitope occurrence. Scale bars: $20 \mu \mathrm{m}$. 

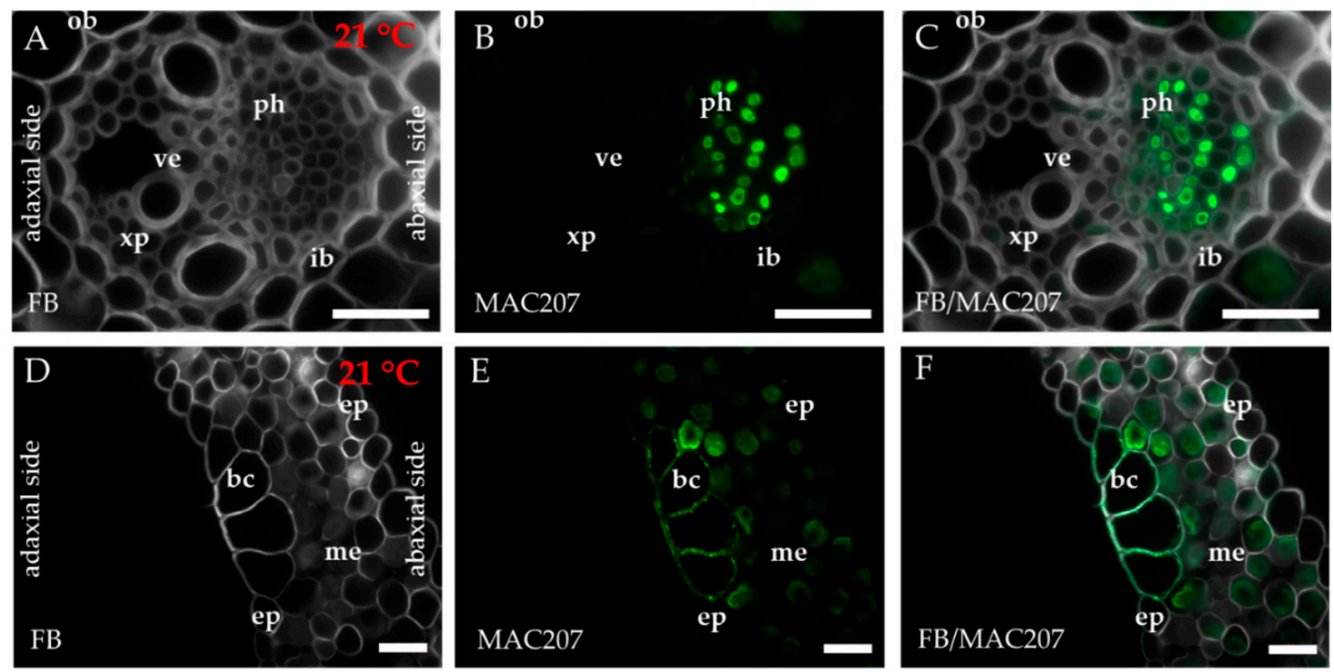

Figure A3. Immunolocalisation of the MAC207 epitope in cross-sections of $B$. distachyon leaves $\left(21{ }^{\circ} \mathrm{C}\right),(\mathbf{A}-\mathbf{C})$ : through the major vascular bundle; (D-F): through the mesophyll and bulliform cells. Abbreviations: ep-epidermis, b-bulliform cells, FB-fluorescent brightener, ib-inner bundle sheath, me-mesophyll, ob-outer bundle sheath, ph-phloem, ve-vessels, xp—xylem parenchyma. The green colour shows epitope occurrence. Scale bars: $20 \mu \mathrm{m}$.
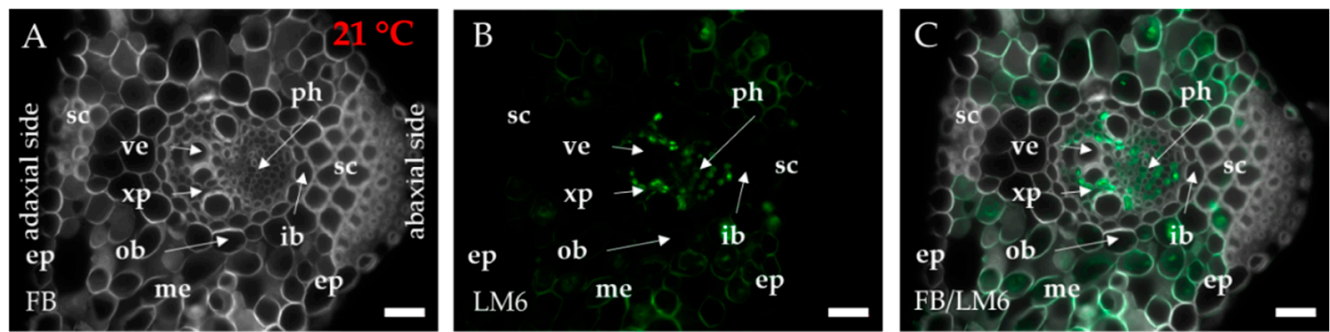

Figure A4. Immunolocalisation of the LM6 epitope (A-C) in cross-sections of B. distachyon leaves $\left(21{ }^{\circ} \mathrm{C}\right)$, through the major vascular bundle. The white arrows point to the respective parts of the leaf. Abbreviations: ep-epidermis, FB-fluorescent brightener, ib-inner bundle sheath, me-mesophyll, o-outer bundle sheath, ph-phloem, sc—sclerenchyma ve-vessels, xp-xylem parenchyma. The green colour shows epitope occurrence. Scale bars: $20 \mu \mathrm{m}$. 

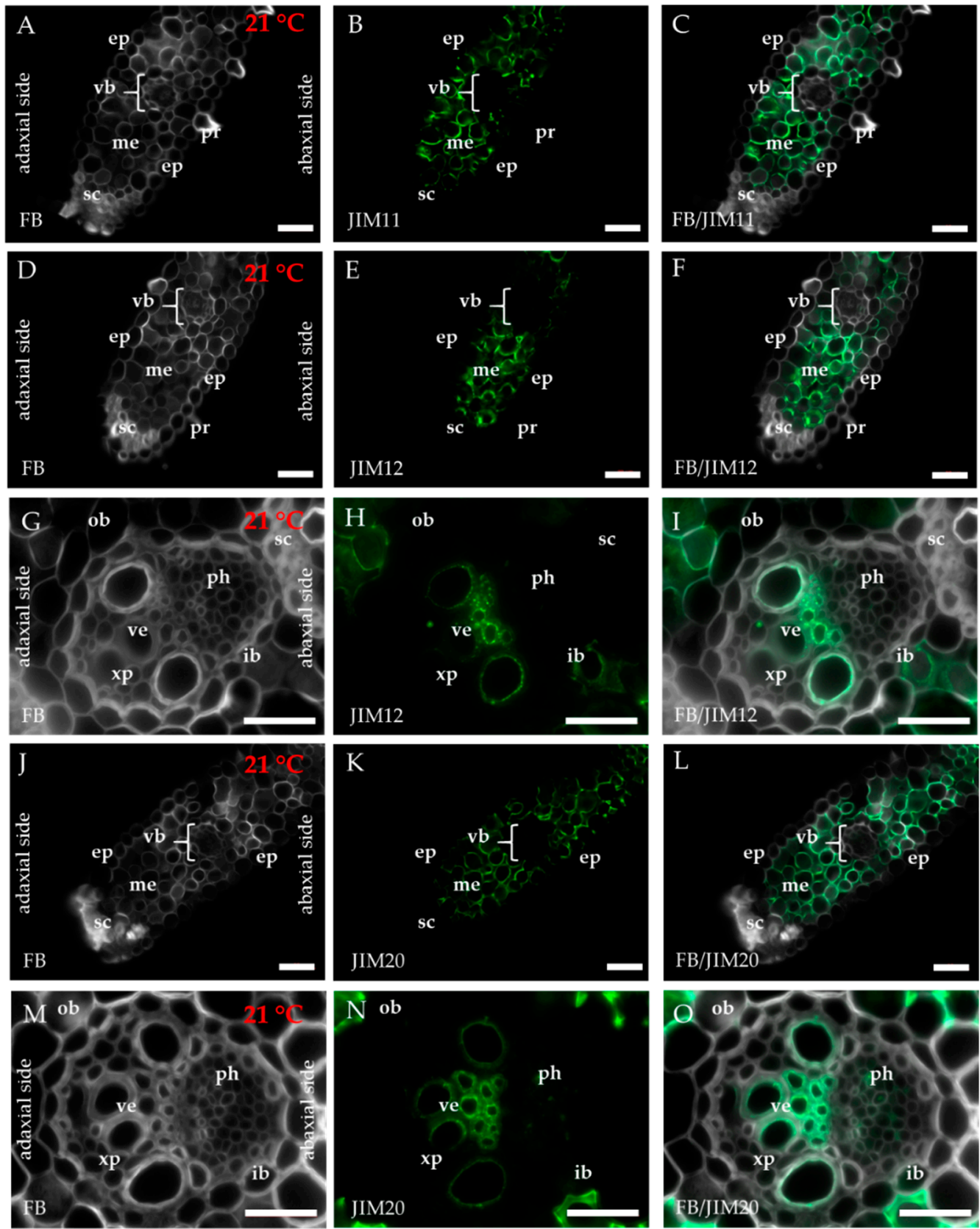

Figure A5. Immunolocalisation of the JIM11 (A-I), JIM12 (D-I) and JIM20 (J-O) epitopes in cross-sections of $B$. distachyon leaves $\left(21^{\circ} \mathrm{C}\right),(\mathbf{A}-\mathbf{F}, \mathbf{J}-\mathbf{L})$ : through the edge of the leaf blade; $(\mathbf{G}-\mathbf{I}, \mathbf{M}-\mathbf{O})$ : through the major vascular bundle. Abbreviations: bc-bulliform cells, ep-epidermis, FB-fluorescent brightener, ib —inner bundle sheath, me - mesophyll, ob—outer bundle sheath, p—phloem, pr-prickle, sc - sclerenchyma, vb—vascular bundle, ve-vessels, $x p$ - xylem parenchyma. The green colour shows epitope occurrence. Scale bars: $20 \mu \mathrm{m}$. 
Table A1. The oligonucleotide primers that were used for the RT-qPCR reaction with relevant descriptions of the genes.

\begin{tabular}{|c|c|c|}
\hline Genes & Description of the Genes & Primer Sequence $\left(5^{\prime}-3^{\prime}\right)$ \\
\hline Bradi1g32860 & ubiquitin & $\begin{array}{l}\text { pF-GAGGGTGGACTCCTTTTGGA } \\
\text { pR-TCCACACTCCACTTGGTGCT }\end{array}$ \\
\hline \multicolumn{3}{|c|}{$E X T$ and $E X T$-like receptor kinase } \\
\hline Bradi4g11250 & extensin (chimeric EXT) & $\begin{array}{l}\text { pF-GCGACTGCGACAATGATGTG } \\
\text { pR-ACCCCTTGCTAAGCCCTCTA }\end{array}$ \\
\hline Bradi3g12902 & extensin (chimeric EXT) & $\begin{array}{l}\text { pF-CATCTGGACCTGCCAATGGT } \\
\text { pR-TCCCAGTTTTGGAGTCTCGC }\end{array}$ \\
\hline Bradi3g59780 & formin-homolog extensin (FH EXT) & $\begin{array}{l}\text { pF-GATGAATGCCGGAACAGCAC } \\
\text { pR-GTGGAGAAGAGTGGTGCCTC }\end{array}$ \\
\hline Bradi4g03720 & formin-homolog extensin (FH EXT) & $\begin{array}{l}\text { pF-GAAGCAGATTGAGGCCGAGA } \\
\text { pR-CGCGCCTCCATCTTTTGATT }\end{array}$ \\
\hline Bradi1g22980 & formin-homolog extensin (FH EXT) & $\begin{array}{l}\text { pF-CAGCAGAGCCTGTTGCTTGAC } \\
\text { pR-TTCTAGGTTTCCGTGCATGAGT }\end{array}$ \\
\hline Bradi2g 49240 & $\begin{array}{l}\text { proline-rich extensin-like receptor kinase } \\
(\text { (PERK) }\end{array}$ & $\begin{array}{l}\text { pF-TTCTCAGCCGTTGGGAGATG } \\
\text { pR-GGAAGGTCCCCAAAGTCTCG }\end{array}$ \\
\hline Bradi1g07010 & $\begin{array}{c}\text { proline-rich extensin-like receptor kinase } \\
(\text { PERK) }\end{array}$ & $\begin{array}{l}\text { pF-CCTCCACGGTAAAGGGCTG } \\
\text { pR-GATCCGTGGATGGCAGTCTT }\end{array}$ \\
\hline Bradi3g31967 & $\begin{array}{l}\text { proline-rich extensin-like receptor kinase } \\
\text { (PERK) }\end{array}$ & $\begin{array}{l}\text { pF-CCGTCGCCATTAAGAATCTGC } \\
\text { pR-GATTCTTGTGCCGAACTCGC }\end{array}$ \\
\hline Bradi2g00900 & $\begin{array}{l}\text { proline-rich extensin-like receptor kinase } \\
(P E R K)\end{array}$ & $\begin{array}{l}\text { pF-TAACTTTGAGGCACAGGTTGCT } \\
\text { pR-AGCCATGTATCCAAAAGTCCCC }\end{array}$ \\
\hline \multicolumn{3}{|c|}{$F L A$} \\
\hline Bradi2g00220 & fasciclin-like arabinogalactan protein & $\begin{array}{l}\text { pF-AGCTCAACAGCTCCCAGAC } \\
\text { pR-CGAAAGCGAGTTGAGCGTG }\end{array}$ \\
\hline Bradi5g18950 & fasciclin-like arabinogalactan protein & $\begin{array}{l}\text { pF-AATAAAGGGAAGTCACCGTCGC } \\
\text { pR-CCGTTCTTCTTGTCATGGACCT }\end{array}$ \\
\hline Bradi4g34420 & fasciclin-like arabinogalactan protein & $\begin{array}{l}\text { pF-CACATCCTCCAGATGCACGTC } \\
\text { pR-CCGGACTCCTGGAACATGG }\end{array}$ \\
\hline Bradi3g39740 & fasciclin-like arabinogalactan protein & $\begin{array}{l}\text { pF-GTACTATTCCCTGGCGGAGTTC } \\
\text { pR-CCATGTTGTCGGTGAGGTTGAG }\end{array}$ \\
\hline Bradi2g60270 & fasciclin-like arabinogalactan protein & $\begin{array}{l}\text { pF-AGCAGAGCAATCCTCTAGTAGC } \\
\text { pR-TGGGTTCTTCTCGCCATTGTTA }\end{array}$ \\
\hline
\end{tabular}

\section{References}

1. Barlow, K.M.; Christy, B.P.; O'Leary, G.J.; Riffkin, P.A.; Nuttall, J.G. Simulating the impact of extreme heat and frost events on wheat crop production: A review. Field Crops Res. 2015, 171, 109-119. [CrossRef]

2. Hatfield, J.L.; Prueger, J.H. Temperature extremes: Effect on plant growth and development. Weather Clim. Extrem. 2015, 10, 4-10. [CrossRef]

3. Ohama, N.; Sato, H.; Shinozaki, K.; Yamaguchi-Shinozaki, K. Transcriptional regulatory network of plant heat stress response. Trends Plant Sci. 2017, 22, 53-65. [CrossRef]

4. Garvin, D.F.; Gu, Y.Q.; Hasterok, R.; Hazen, S.P.; Jenkins, G.; Mockler, T.C.; Mur, L.A.J.; Vogel, J.P. Development of genetic and genomic research resources for Brachypodium distachyon, a new model system for grass crop research. Crop Sci. 2008, 48, S-69. [CrossRef]

5. International Brachypodium Initiative. Genome sequencing and analysis of the model grass Brachypodium distachyon. Nature 2010, 463, 763-768. [CrossRef] [PubMed] 
6. Janmohammadi, M.; Zolla, L.; Rinalducci, S. Low temperature tolerance in plants: Changes at the protein level. Phytochemistry 2015, 117, 76-89. [CrossRef]

7. Bita, C.E.; Gerats, T. Plant tolerance to high temperature in a changing environment: Scientific fundamentals and production of heat stress-tolerant crops. Front. Plant Sci. 2013, 4, 273. [CrossRef]

8. Le Gall, H.; Philippe, F.; Domon, J.M.; Gillet, F.; Pelloux, J.; Rayon, C. Cell wall metabolism in response to abiotic stress. Plants 2015, 4, 112-166. [CrossRef] [PubMed]

9. Johnson, K.L.; Cassin, A.M.; Lonsdale, A.; Bacic, A.; Doblin, M.S.; Schultz, C.J. Pipeline to identify hydroxyproline-rich glycoproteins. Plant Physiol. 2017, 174, 886-903. [CrossRef] [PubMed]

10. Pereira, A.M.; Pereira, L.G.; Coimbra, S. Arabinogalactan proteins: Rising attention from plant biologists. Plant Reprod. 2015, 28, 1-15. [CrossRef] [PubMed]

11. Showalter, A.M.; Basu, D. Extensin and arabinogalactan-protein biosynthesis: Glycosyltransferases, research challenges, and biosensors. Front. Plant Sci. 2016, 7, 814. [CrossRef] [PubMed]

12. Su, S.; Higashiyama, T. Arabinogalactan proteins and their sugar chains: Functions in plant reproduction, research methods, and biosynthesis. Plant Reprod. 2018, 31, 67-75. [CrossRef]

13. Baetz, U.; Martinoia, E. Root exudates: The hidden part of plant defense. Trends Plant Sci. 2014, 19, 90-98. [CrossRef] [PubMed]

14. Pinski, A.; Betekhtin, A.; Hupert-Kocurek, K.; Mur, L.A.J.; Hasterok, R. Defining the genetic basis of plant-endophytic bacteria interactions. Int. J. Mol. Sci. 2019, 20, 1947. [CrossRef] [PubMed]

15. Betekhtin, A.; Rojek, M.; Nowak, K.; Pinski, A.; Milewska-Hendel, A.; Kurczynska, E.; Doonan, J.H.; Hasterok, R. Cell wall epitopes and endoploidy as reporters of embryogenic potential in Brachypodium distachyon callus culture. Int. J. Mol. Sci. 2018, 19, 3811. [CrossRef] [PubMed]

16. Mareri, L.; Romi, M.; Cai, G. Arabinogalactan proteins: Actors or spectators during abiotic and biotic stress in plants? Plant Biosyst. 2018, 153, 173-185. [CrossRef]

17. Mareri, L.; Faleri, C.; Romi, M.; Mariani, C.; Cresti, M.; Cai, G. Heat stress affects the distribution of JIM8-labelled arabinogalactan proteins in pistils of Solanum lycopersicum cv Micro-Tom. Acta Physiol. Plant 2016, 38, 184. [CrossRef]

18. Yan, Y.; Takac, T.; Li, X.; Chen, H.; Wang, Y.; Xu, E.; Xie, L.; Su, Z.; Samaj, J.; Xu, C. Variable content and distribution of arabinogalactan proteins in banana (Musa spp.) under low temperature stress. Front. Plant Sci. 2015, 6, 353. [CrossRef]

19. Liu, X.; Wolfe, R.; Welch, L.R.; Domozych, D.S.; Popper, Z.A.; Showalter, A.M. Bioinformatic identification and analysis of extensins in the plant kingdom. PLoS ONE 2016, 11, e0150177. [CrossRef]

20. Betekhtin, A.; Rojek, M.; Milewska-Hendel, A.; Gawecki, R.; Karcz, J.; Kurczynska, E.; Hasterok, R. Spatial distribution of selected chemical cell wall components in the embryogenic callus of Brachypodium distachyon. PLoS ONE 2016, 11, e0167426. [CrossRef]

21. Castilleux, R.; Plancot, B.; Ropitaux, M.; Carreras, A.; Leprince, J.; Boulogne, I.; Follet-Gueye, M.L.; Popper, Z.A.; Driouich, A.; Vicre, M. Cell wall extensins in root-microbe interactions and root secretions. J. Exp. Bot. 2018, 69, 4235-4247. [CrossRef] [PubMed]

22. Baumberger, N.; Ringli, C.; Keller, B. Systematic identification of novel protein domain families associated with nuclear functions. Genome Res. 2002, 12, 47-56.

23. Botha, C.E. A tale of two neglected systems-structure and function of the thin- and thick-walled sieve tubes in monocotyledonous leaves. Front. Plant Sci. 2013, 4, 297. [CrossRef]

24. Gawecki, R.; Sala, K.; Kurczyńska, E.U.; Świątek, P.; Płachno, B.J. Immunodetection of some pectic, arabinogalactan proteins and hemicellulose epitopes in the micropylar transmitting tissue of apomictic dandelions (Taraxacum, Asteraceae, Lactuceae). Protoplasma 2016, 254, 657-668. [CrossRef] [PubMed]

25. Milewska-Hendel, A.; Baczewska, A.H.; Sala, K.; Dmuchowski, W.; Bragoszewska, P.; Gozdowski, D.; Jozwiak, A.; Chojnacki, T.; Swiezewska, E.; Kurczynska, E. Quantitative and qualitative characteristics of cell wall components and prenyl lipids in the leaves of Tilia x euchlora trees growing under salt stress. PLoS ONE 2017, 12, e0172682. [CrossRef]

26. Garaeva, L.D.; Pozdeeva, S.A.; Timofeeva, O.A.; Khokhlova, L.P. Cell-wall lectins during winter wheat cold hardening. Russ. J. Plant. Physiol. 2006, 53, 746-750. [CrossRef]

27. Gong, S.Y.; Huang, G.Q.; Sun, X.; Li, P.; Zhao, L.L.; Zhang, D.J.; Li, X.B. GhAGP31, a cotton non-classical arabinogalactan protein, is involved in response to cold stress during early seedling development. Plant. Biol. 2012, 14, 447-457. [CrossRef] [PubMed] 
28. Kang, Y.; Khan, S.; Ma, X. Climate change impacts on crop yield, crop water productivity and food security-A review. Prog. Nat. Sci. 2009, 19, 1665-1674. [CrossRef]

29. Wang, W.; Vinocur, B.; Altman, A. Plant responses to drought, salinity and extreme temperatures: Towards genetic engineering for stress tolerance. Planta 2003, 218, 1-14. [CrossRef]

30. Larsen, F.H.; Byg, I.; Damager, I.; Diaz, J.; Engelsen, S.B.; Ulvskov, P. Residue specific hydration of primary cell wall potato pectin identified by solid-state 13C single-pulse MAS and CP/MAS NMR spectroscopy. Biomacromolecules 2011, 12, 1844-1850. [CrossRef] [PubMed]

31. Ha, M.A.; Vietor, R.J.; Jardine, G.D.; Apperley, D.C.; Jarvis, M.C. Conformation and mobility of the arabinan and galactan side-chains of pectin. Phytochemistry 2005, 66, 1817-1824. [CrossRef]

32. Tenhaken, R. Cell wall remodeling under abiotic stress. Front. Plant. Sci. 2014, 5, 771. [CrossRef]

33. Moore, J.P.; Farrant, J.M.; Driouich, A. A role for pectin-associated arabinans in maintaining the flexibility of the plant cell wall during water deficit stress. Plant. Signal. Behav. 2014, 3, 102-104. [CrossRef]

34. Betekhtin, A.; Pinski, A.; Milewska-Hendel, A.; Kurczynska, E.; Hasterok, R. Stability and instability processes in the calli of Fagopyrum tataricum that have different morphogenic potentials. Plant. Cell Tissue Organ. Cult. 2019, 1-15. [CrossRef]

35. Xue, H.; Seifert, G.J. Fasciclin like arabinogalactan protein 4 and respiratory burst oxidase homolog d and $\mathrm{F}$ independently modulate abscisic acid signaling. Plant. Signal. Behav. 2015, 10, e989064. [CrossRef]

36. Johnson, K.L.; Jones, B.J.; Bacic, A.; Schultz, C.J. The fasciclin-like arabinogalactan proteins of Arabidopsis. A multigene family of putative cell adhesion molecules. Plant. Physiol. 2003, 133, 1911-1925. [CrossRef]

37. Seifert, G.J.; Xue, H.; Acet, T. The Arabidopsis thaliana FASCICLIN LIKE ARABINOGALACTAN PROTEIN 4 gene acts synergistically with abscisic acid signalling to control root growth. Ann. Bot. 2014, 114, 1125-1133. [CrossRef]

38. Faik, A.; Abouzouhair, J.; Sarhan, F. Putative fasciclin-like arabinogalactan-proteins (FLA) in wheat (Triticum aestivum) and rice (Oryza sativa): Identification and bioinformatic analyses. Mol. Genet. Genom. 2006, 276, 478-494. [CrossRef]

39. Ma, H.; Zhao, J. Genome-wide identification, classification, and expression analysis of the arabinogalactan protein gene family in rice (Oryza sativa L.). J. Exp. Bot. 2010, 61, 2647-2668. [CrossRef]

40. Nahar, K.; Hasanuzzaman, M.; Ahamed, K.U.; Hakeem, K.R.; Ozturk, M.; Fujita, M. Plant responses and tolerance to high temperature stress: Role of exogenous phytoprotectants. In Crop Production and Global Environmental Issues; Hakeem, K.R., Ed.; Springer International Publishing: Cham, The Netherlands, 2015; pp. 385-435.

41. Ellis, M.; Egelund, J.; Schultz, C.J.; Bacic, A. Arabinogalactan-proteins: Key regulators at the cell surface? Plant. Physiol. 2010, 153, 403-419. [CrossRef]

42. Lima, R.B.; dos Santos, T.B.; Vieira, L.G.; Ferrarese Mde, L.; Ferrarese-Filho, O.; Donatti, L.; Boeger, M.R.; Petkowicz, C.L. Heat stress causes alterations in the cell-wall polymers and anatomy of coffee leaves (Coffea arabica L.). Carbohydr. Polym. 2013, 93, 135-143. [CrossRef]

43. Olmos, E.; Garcia De La Garma, J.; Gomez-Jimenez, M.C.; Fernandez-Garcia, N. Arabinogalactan proteins are involved in salt-adaptation and vesicle trafficking in tobacco by-2 cell cultures. Front. Plant Sci. 2017, 8 , 1092. [CrossRef]

44. Zang, L.; Zheng, T.; Chu, Y.; Ding, C.; Zhang, W.; Huang, Q.; Su, X. Genome-wide analysis of the fasciclin-like arabinogalactan protein gene family reveals differential expression patterns, localization, and salt stress response in Populus. Front. Plant Sci. 2015, 6, 1140. [CrossRef] [PubMed]

45. Lamport, D.T.; Kieliszewski, M.J.; Showalter, A.M. Salt stress upregulates periplasmic arabinogalactan proteins: Using salt stress to analyse AGP function. New Phytol. 2006, 169, 479-492. [CrossRef] [PubMed]

46. Shi, H.; Kim, Y.; Guo, Y.; Stevenson, B.; Zhu, J.K. The Arabidopsis SOS5 locus encodes a putative cell surface adhesion protein and is required for normal cell expansion. Plant. Cell 2002, 15, 19-32. [CrossRef] [PubMed]

47. Griffiths, J.S.; Tsai, A.Y.; Xue, H.; Voiniciuc, C.; Sola, K.; Seifert, G.J.; Mansfield, S.D.; Haughn, G.W. SALT-OVERLY SENSITIVE5 mediates Arabidopsis seed coat mucilage adherence and organization through pectins. Plant Physiol. 2014, 165, 991-1004. [CrossRef] [PubMed]

48. Seifert, G.J. Fascinating fasciclins: A surprisingly widespread family of proteins that mediate interactions between the cell exterior and the cell surface. Int. J. Mol. Sci. 2018, 19, 1628. [CrossRef] [PubMed] 
49. Johnson, K.L.; Kibble, N.A.; Bacic, A.; Schultz, C.J. A fasciclin-like arabinogalactan-protein (FLA) mutant of Arabidopsis thaliana, fla1, shows defects in shoot regeneration. PLoS ONE 2011, 6, e25154. [CrossRef]

50. Wu, Y.; Fan, W.; Li, X.; Chen, H.; Takac, T.; Samajova, O.; Fabrice, M.R.; Xie, L.; Ma, J.; Samaj, J.; et al. Expression and distribution of extensins and AGPs in susceptible and resistant banana cultivars in response to wounding and Fusarium oxysporum. Sci. Rep. 2017, 7, 42400. [CrossRef]

51. Casero, P.J.; Casimiro, I.; Knox, J.P. Occurrence of cell surface arabinogalactan-protein and extensin epitopes in relation to pericycle and vascular tissue development in the root apex of four species. Planta 1998, 204, 252-259. [CrossRef]

52. Zhang, X.; Ren, Y.; Zhao, J. Roles of extensins in cotyledon primordium formation and shoot apical meristem activity in Nicotiana tabacum. J. Exp. Bot. 2008, 59, 4045-4058. [CrossRef] [PubMed]

53. Xu, C.; Takáč, T.; Burbach, C.; Menzel, D.; Šamaj, J. Developmental localization and the role of hydroxyproline rich glycoproteins during somatic embryogenesis of banana (Musa spp. AAA). BMC Plant. Biol. 2011, 11, 38. [CrossRef]

54. Zhang, X.; Ma, H.; Qi, H.; Zhao, J. Roles of hydroxyproline-rich glycoproteins in the pollen tube and style cell growth of tobacco (Nicotiana tabacum L.). J. Plant. Physiol. 2014, 171, 1036-1045. [CrossRef] [PubMed]

55. Seki, M.; Narusaka, M.; Ishida, J.; Nanjo, T.; Fujita, M.; Oono, Y.; Kamiya, A.; Nakajima, M.; Enju, A.; Sakurai, T.; et al. Monitoring the expression profiles of 7000 Arabidopsis genes under drought, cold and high-salinity stresses using a full-length cDNA microarray. Plant. J. 2002, 31, 279-292. [CrossRef] [PubMed]

56. Kreps, J.A.; Wu, Y.; Chang, H.S.; Zhu, T.; Wang, X.; Harper, J.F. Transcriptome changes for Arabidopsis in response to salt, osmotic, and cold stress. Plant. Physiol. 2002, 130, 2129-2141. [CrossRef]

57. Hwang, Y.; Lee, H.; Lee, Y.S.; Cho, H.T. Cell wall-associated ROOT HAIR SPECIFIC 10, a proline-rich receptor-like kinase, is a negative modulator of Arabidopsis root hair growth. J. Exp. Bot. 2016, 67, 2007-2022. [CrossRef]

58. Dar, N.A.; Amin, I.; Wani, W.; Shafiq, A.; Shikari, A.B.; Wani, S.H.; Masoodi, K.Z. Abscisic acid: A key regulator of abiotic stress tolerance in plants. Plant. Gene 2017, 11, 106-111. [CrossRef]

59. Bai, L.; Zhang, G.; Zhou, Y.; Zhang, Z.; Wang, W.; Du, Y.; Wu, Z.; Song, C.P. Plasma membrane-associated proline-rich extensin-like receptor kinase 4 , a novel regulator of $\mathrm{Ca}$ signalling, is required for abscisic acid responses in Arabidopsis thaliana. Plant. J. 2009, 60, 314-327. [CrossRef] [PubMed]

60. Silva, N.F.; Goring, D.R. The proline-rich, extensin-like receptor kinase-1 (PERK1) gene is rapidly induced by wounding. Plant. Mol. Biol. 2002, 50, 667-685. [CrossRef]

61. Zhao, C.; Zayed, O.; Yu, Z.; Jiang, W.; Zhu, P.; Hsu, C.C.; Zhang, L.; Tao, W.A.; Lozano-Duran, R.; Zhu, J.K. Leucine-rich repeat extensin proteins regulate plant salt tolerance in Arabidopsis. Proc. Natl. Acad. Sci. USA 2018, 115, 13123-13128. [CrossRef]

62. Irizarry, I.; White, J.F. Bacillus amyloliquefaciens alters gene expression, ROS production and lignin synthesis in cotton seedling roots. J. Appl. Microbiol. 2018, 124, 1589-1603. [CrossRef]

63. Sujkowska-Rybkowska, M.; Borucki, W. Accumulation and localization of extensin protein in apoplast of pea root nodule under aluminum stress. Micron 2014, 67, 10-19. [CrossRef]

64. Francin-Allami, M.; Merah, K.; Albenne, C.; Rogniaux, H.; Pavlovic, M.; Lollier, V.; Sibout, R.; Guillon, F.; Jamet, E.; Larre, C. Cell wall proteomic of Brachypodium distachyon grains: A focus on cell wall remodeling proteins. Proteomics 2015, 15, 2296-2306. [CrossRef]

65. Calderan-Rodrigues, M.J.; Guimarães Fonseca, J.; de Moraes, F.E.; Vaz Setem, L.; Carmanhanis Begossi, A.; Labate, C.A. Plant cell wall proteomics: A focus on monocot species, Brachypodium distachyon, Saccharum spp. and Oryza sativa. Int. J. Mol. Sci. 2019, 20, 1975. [CrossRef] [PubMed]

66. Douche, T.; San Clemente, H.; Burlat, V.; Roujol, D.; Valot, B.; Zivy, M.; Pont-Lezica, R.; Jamet, E. Brachypodium distachyon as a model plant toward improved biofuel crops: Search for secreted proteins involved in biogenesis and disassembly of cell wall polymers. Proteomics 2013, 13, 2438-2454. [CrossRef] [PubMed]

67. Francin-Allami, M.; Lollier, V.; Pavlovic, M.; San Clemente, H.; Rogniaux, H.; Jamet, E.; Guillon, F.; Larre, C. Understanding the remodelling of cell walls during Brachypodium distachyon grain development through a sub-cellular quantitative proteomic approach. Proteomes 2016, 4, 21. [CrossRef]

68. Zhang, M.; Chen, G.X.; Lv, D.W.; Li, X.H.; Yan, Y.M. N-linked glycoproteome profiling of seedling leaf in Brachypodium distachyon L. J. Proteome Res. 2015, 14, 1727-1738. [CrossRef] [PubMed] 
69. Priest, H.D.; Fox, S.E.; Rowley, E.R.; Murray, J.R.; Michael, T.P.; Mockler, T.C. Analysis of global gene expression in Brachypodium distachyon reveals extensive network plasticity in response to abiotic stress. PLOS ONE 2014, 9, e87499. [CrossRef]

70. Hong, S.Y.; Park, J.H.; Cho, S.H.; Yang, M.S.; Park, C.M. Phenological growth stages of Brachypodium distachyon: Codification and description. Weed Res. 2011, 51, 612-620. [CrossRef]

71. Sala, K.; Malarz, K.; Barlow, P.W.; Kurczyńska, E.U. Distribution of some pectic and arabinogalactan protein epitopes during Solanum lycopersicum (L.) adventitious root development. BMC Plant. Biol. 2017, 17, 25. [CrossRef] [PubMed]

72. Betekhtin, A.; Milewska-Hendel, A.; Chajec, L.; Rojek, M.; Nowak, K.; Kwasniewska, J.; Wolny, E.; Kurczynska, E.; Hasterok, R. 5-azacitidine induces cell death in a tissue culture of Brachypodium distachyon. Int. J. Mol. Sci. 2018, 19, 1806. [CrossRef] [PubMed]

73. Pennell, R.I.; Janniche, L.; Kjellbom, P.; Scofield, G.N.; Peart, J.M.; Roberts, K. Developmental regulation of a plasma membrane arabinogalactan protein epitope in oilseed rape flowers. Plant. Cell 1991, 3, 1317-1326. [CrossRef] [PubMed]

74. Yates, E.A.; Knox, J.P. Investigations into the occurrence of plant cell surface epitopes in exudate gums. Carbohydr. Polym. 1994, 24, 281-286. [CrossRef]

75. Yates, E.A.; Valdor, J.F.; Haslam, S.M.; Morris, H.R.; Dell, A.; Mackie, W.; Knox, J.P. Characterization of carbohydrate structural features recognized by anti-arabinogalactan-protein monoclonal antibodies. Glycobiology 1996, 6, 131-139. [CrossRef]

76. Knox, J.P.; Linstead, P.J.; Peart, J.; Cooper, C.; Roberts, K. Developmentally regulated epitopes of cell surface arabinogalactan proteins and their relation to root tissue pattern formation. Plant. J. 1991, 1, 317-326. [CrossRef] [PubMed]

77. Smallwood, M.; Yates, E.A.; Willats, W.G.T.; Martin, H.; Knox, J.P. Immunochemical comparison of membrane-associated and secreted arabinogalactan-proteins in rice and carrot. Planta 1996, 198, 452-459. [CrossRef]

78. Bradley, D.J.; Wood, E.A.; Larkins, A.P.; Galfre, G.; Butcher, G.W.; Brewin, N.J. Isolation of monoclonal antibodies reacting with peribacteroid membranes and other components of pea root nodules containing Rhizobium leguminosarum. Planta 1988, 173, 149-160. [CrossRef] [PubMed]

79. Pennell, R.I.; Knox, J.P.; Scofield, G.N.; Selvendran, R.R.; Roberts, K. A family of abundant plasma membrane-associated glycoproteins related to the arabinogalactan proteins is unique to flowering plants. J. Cell. Biol. 1989, 108, 1967-1977. [CrossRef]

80. Willats, W.G.T.; Marcus, S.E.; Knox, J.P. Generation of a monoclonal antibody specific to $(1 \rightarrow 5)-\alpha$-L-arabinan. Carbohydr. Res. 1998, 308, 149-152. [CrossRef]

81. El-Tantawy, A.A.; Solis, M.T.; Da Costa, M.L.; Coimbra, S.; Risueno, M.C.; Testillano, P.S. Arabinogalactan protein profiles and distribution patterns during microspore embryogenesis and pollen development in Brassica napus. Plant. Reprod. 2013, 26, 231-243. [CrossRef] [PubMed]

82. Smallwood, M.; Beven, A.; Donovan, N.; Neill, S.J.; Peart, J.; Roberts, K.; Knox, J.P. Localization of cell wall proteins in relation to the developmental anatomy of the carrot root apex. Plant. J. 1994, 5, 237-246. [CrossRef]

(C) 2019 by the authors. Licensee MDPI, Basel, Switzerland. This article is an open access article distributed under the terms and conditions of the Creative Commons Attribution (CC BY) license (http://creativecommons.org/licenses/by/4.0/). 